\title{
Donald Trump and the Lie
}

[This version: March 8, 2021]

Kevin Arceneaux ${ }^{\dagger} \&$ Rory Truex ${ }^{\ddagger}$

\begin{abstract}
The legitimacy of democratically elected governments rests in part on widespread acceptance of the outcome of elections, especially among those who lost. This "losers' consent" allows the winners to govern and, when the incumbent is the losing party, it allows for a peaceful transition of power. What happens in a democratic system when one side not only refuses to concede, but actively perpetuates lies about the outcome? This paper studies the consequences of a Donald Trump's "big lie" using a daily tracking survey, yielding 40-days of polls and over 20,000 responses from American voters. We find that the lie is pervasive and sticky - the number of Republicans and independents believing that the election was fraudulent is substantial, and this proportion did not change appreciably over time or shift after important political developments. In reaction to the lie, and the threat it brought to the transition of power, there was a significant rise in support for political violence among Democrats, support that only waned after the insurrection of January 6th. We also find there are likely significant, long term consequences to the lie. Republican voters will reward politicians that perpetuate it in the next electoral cycle.
\end{abstract}

Keywords: 2020 US Presidential Election | Democratic Legitimacy | WinnersLosers Gap | Losers' Consent

\footnotetext{
${ }^{\dagger}$ Thomas J. Freaney Jr. Professor of Political Science, Temple University. kevin.arceneaux@temple.edu.

${ }^{\ddagger}$ Assistant Professor of Politics and International Affairs, Princeton University. rtruex@princeton.edu. Our gratitude goes to the University Center for Human Values and Data Driven Social Science Initiative at Princeton University for funding support. Additional financial support was provided by Temple University.
} 
The legitimacy of democratically elected governments rests in part on widespread acceptance of the outcome of elections, especially among those who lost. This "losers' consent" allows the winners to govern and, when the incumbent is the losing party, it allows for a peaceful transition of power (Anderson et al. 2005). Evidence from "consolidating" democracies shows that when politicians and their supporters refuse to accept defeat, it decreases support for the political system and increases the likelihood of attempts to overthrow the government through violent means (Przeworski 1991, 2005). Consequently, the willingness for incumbent politicians to accept defeat is a crucial test for democratic stability (Huntington 1991).

Politicians and voters alike do not like to be on the losing side (Anderson et al. 2005; Sances and Stewart 2015). Voters are sometimes willing to indulge a form of outcome bias in which they judge the integrity of an election based on whether their party's candidate won or lost (Baron and Hershey 1988; Cantú and García-Ponce 2015). As a result, the losing candidate of an election has an incentive to assert that fraud and irregularities explain the outcome, rather than conceding that a plurality or majority of voters have rejected him or her. In countries with weak commitments to democracy, it is not uncommon for incumbents to make dubious charges of fraud when elections do not turn out as they wanted (Schedler 2001), and their supporters often believe them (Cantú and García-Ponce 2015). Our point of departure is to consider these dynamics in the United States, one of the world's long-standing "consolidated" democracies.

The goal of this paper is to study how blatant lies shape voters' perceptions about election integrity, support for violence, and ultimately, democratic stability. Most of our knowledge about lies and politics comes from the study of authoritarian countries. In these systems, citizens are obligated to live "within the lie" and behave "as if" they believe (Havel 2018; Wedeen 2015). Many come to internalize those lies, though some do not, and it is difficult to discern who really believes what (Kuran 1991; Shen and Truex 2020). Dictators create an atmosphere in which their regime is continually portrayed as powerful, infallible, and the 
only viable option. ${ }^{1}$

Authoritarian regimes often propagate so-called "big lies," those that are so grand that people believe no one would have the gall to make them up. Adolph Hitler infamously describes this strategy in Mein Kampf:

[I]n the big lie there is always a certain force of credibility; because the broad masses of a nation are always more easily corrupted in the deeper strata of their emotional nature than consciously or voluntarily; and thus in the primitive simplicity of their minds they more readily fall victims to the big lie than the small lie, since they themselves often tell small lies in little matters but would be ashamed to resort to large-scale falsehoods. It would never come into their heads to fabricate colossal untruths, and they would not believe that others could have the impudence to distort the truth so infamously.

Because the government has a monopoly over mass media, lies can spread and thrive relatively unchecked in many authoritarian systems.

It is unclear that such an approach would be effective in a liberal democratic system like the United States. On the one hand, the presence of robust political competition and a free press often works to limit the ability of politicians to manipulate public opinion (Chong and Druckman 2007; Zaller 1992). A cornerstone assumption in American free speech jurisprudence is that in a "marketplace of ideas" truth wins out over falsehood (Brazeal 2011). On the other, as partisan polarization transmogrifies into partisan sectarianism in the United States, it provides fertile ground for blatant lies pedaled by politicians to take root and go unchecked by their partisans (Finkel et al. 2020; Druckman, Peterson and Slothuus 2013; Van Bavel and Pereira 2018).

The 2020 presidential election offers an unparalleled opportunity to study whether a "big lie" spread by mainstream political actors can shape public perceptions in an established democracy. The ritual of losing gracefully is a hallmark of stable, consolidated democracies, including the United States. Breaking with long-held tradition, former President Donald J. Trump refused to accept that he had lost the election to Joe Biden. Even after the courts ${ }^{1}$ Emerging work on propaganda, for example, suggests that its intention is not necessarily to persuade but to signal strength (Huang 2015). 
rejected nearly 40 lawsuits filed by his campaign, he continued to repeat debunked conspiracy theories about how the election had been stolen from him. In a shocking turn of events, a mob of Trump's supporters laid siege to the Capitol building while congress members met to officially certify the election for Biden. Their rampage interrupted the proceedings, put legislators in grave danger, and ended with the deaths of a police officer and several rioters. Although a transfer of power to President Biden eventually happened as constitutionally proscribed, it did so under heavy guard from soldiers. Not long ago, this set of events happening in the United States would have been unthinkable (Almond and Verba 1963).

In order to shed light on the dynamics of public opinion before and after the 2020 presidential election, we instituted the Election Legitimacy Tracking Survey (ELTS), a nationally descriptive online survey implemented by Qualtrics panels between October 27, 2020 and January 29, 2021 ( $n=20,000)$. We conducted daily surveys of 500 respondents for a month around the election and then biweekly surveys until nine days after President Biden was inaugurated. This rolling cross section design allows us to see how public opinion about the election unfolded in real time. The project is unusual in that we did not know what the primary "treatment" (the election outcome) would be in advance, only that the election itself would likely feature some degree of contestation after the fact. We put the survey in the field in October knowing that the 2020 election would be critical for the future of American democracy, and our goal was to set up a data collection process to document trends in public opinion as richly as possible.

Five key findings emerge from the data. First, we find that a non-trivial number of Americans, particularly those who identify as Republican, accept the lie that Donald Trump was the rightful victor of the 2020 election. Roughly one in four Americans does not believe the election result was legitimate or identify Joe Biden as the winner. For Republicans, these proportions hover around 50\%. Acceptance of the election outcome is lowest for Americans who are older, less educated, and of lower social status.

Second, we observe that the lie is "sticky" - acceptance of the election outcome did not 
change appreciably over time or move significantly in response to the many dramatic political events that unfolded after the election. Attitudes towards the election in late January were roughly the same as they were in mid-November. In some of the survey waves, we showed respondents that denied the Biden victory a series questions of the form, "Would you believe Biden won if..." followed by different hypothetical scenarios. Of the voters that denied the outcome, only $28.7 \%$ said they would believe Biden won if Republican leaders like Mitch McConnell were to say that Biden won more votes. About $31.0 \%$ would believe Biden won if the Electoral College were to award him a majority of votes, and $42.9 \%$ would believe Biden won if there were a Supreme Court decision to that effect. But as those events actually unfolded, we did not observe equivalent increases in acceptance of the election.

Third, we observe that in response the perpetuation of the lie, Americans in general grew more accepting of political violence. This pattern was most prominent for Democrats, whose willingness to accept violence peaked in early December, when Trump was perhaps most brazen in his attempts to thwart the Electoral College vote. The insurrection of January 6th dampened support for violence among Democrats and nonpartisan voters, though levels remained higher than prior to the pre-election baseline.

Fourth, although we observed some Republicans deidentifying with Trump as the election outcome unfolded, the expected pattern of "cutting off reflected failure" was not as dramatic as previous research lead us to anticipate (Hirt et al. 1992; Boen et al. 2002). The "big lie" presented Republican voters with the alternative cognitive strategy of cutting oneself off from reality rather than the candidate. These differing strategies appear responsible for a significant fracture in the Republican party, with some voters accepting reality and deidentifying with Trump, and some accepting the lie and doubling down on their support.

Fifth, we find evidence that the lie has the potential to shape the Republican party and American politics for years to come. Starting in January 2021, we began including a simple "paired conjoint" design in the survey (Hainmueller, Hopkins and Yamamoto 2014; Hainmueller, Hangartner and Yamamoto 2015; Teele, Kalla and Rosenbluth 2018), presenting 
Republican voters with hypothetical primary candidates for an upcoming congressional race. We find that candidates who maintain Donald Trump won the 2020 election have a distinct electoral advantage, about 6 percentage points, versus candidates that do not. Based on these findings, we expect many Republican candidates to perpetuate the lie in the next election cycle, or at the very least, refuse to refute it.

Even though the United States is the focus of our analysis, our findings have implications for other established democracies. Many democracies are experiencing an increase in polarization and the loosening of universal commitment to democratic norms (Przeworski 2019). We do not believe that the United States is exceptional with respect to the possibility that a major political party or actor could profitably forward blatant lies. Our findings also offer additional support to the theoretical position that culture alone cannot sustain democratic norms (Dahl 1989; Przeworski 2005). Even established democracies are fragile, and the strategic decisions made by elites can have potentially dire consequences.

\section{Data and Research Design}

The Election Legitimacy Tracking Survey (ELTS) was conducted online through the Qualtrics survey platform, which recruits participants and verifies their names, addresses, and dates of birth, before inviting them to join their sampling panel. It incentives participation in surveys by compensating respondents with money or money-equivalents (e.g., Amazon points), and it conducts validity checks of responses to produce a high-quality sample. Importantly, the demographic and political representativeness as well as its data quality have been independently verified by scholars (Boas, Christenson and Glick 2020). We restricted the population to American citizens that are registered to vote. ${ }^{2}$

Thee project employs a rolling cross-section design. We received a sample of 500 new respondents every day beginning October 27th, 2020 through November 20th, 2020. After

\footnotetext{
${ }^{2}$ To ensure some balance in the data, we instituted two soft quotas in the collection process on gender and partisanship.
} 
November 20th we switched to collecting samples on Tuesday and Friday of each week, with some pauses in the data collection for holidays. In total we collected 20,000 responses over 40 daily samples through January 29th, 2021. For each daily sample, we calculated poststratification weights to align the sample with known characteristics of the population. Our weighting scheme was implemented using entropy balancing and included information on gender, age, race, partisanship, education, and region (Hainmueller 2012). This process resulted in weighted daily samples that all had the same composition on these five core demographic characteristics and also matched the composition of the American electorate.

Figures SI1 and SI2 in the Supporting Information show the composition of the sample over time for demographic covariates of interest. The dotted lines correspond to the population proportion, and the grey points represent the sample proportion for a given daily sample. We see stability in the sample composition over time, with some small differences from day to day due to sampling variability. The sample skews younger and more educated than the population, and Black voters are slightly over-represented. Departures like these are common in survey research, and the poststratification weights result in daily samples that are tied to population proportion, weighting respondents from underrepresented groups slightly more heavily. The core substantive findings of the paper are not sensitive to this weighting decision (see Supporting Information for figures with unweighted data). Note that weighted opt-in national surveys like ours have increasingly become a common way to gauge public opinion and voting behavior. Empirical evidence suggests they fare just as well at predicting election outcomes as older "traditional" methods like as random-digit dialing (see Kennedy et al. 2018, Figure 4, p. 12).

The core questionnaire was kept largely the same throughout the project. Respondents first answered standard demographic questions and provided information on their partisan affiliations and voting history. The next module included questions on the legitimacy of the election. The remainder of the survey included several standard question batteries to measure support for political violence (Moskalenko and McCauley 2009); the need for chaos (Petersen, 
Osmundsen and Arceneaux 2018); anxiety and depression (Zigmond and Snaith 1983); selfesteem (Schmitt and Allik 2005); and support for democratic norms (Inglehart 2003). These batteries were presented in random order and the question order was also randomized within each battery. The final module was a short Word Association Test that asked respondents the first words that come to mind for several cues, including Donald Trump and Joe Biden. The wordings for key questions used in this paper are included in the Supporting Information

\section{Results}

Perceptions of Legitimacy

Figure 1 shows perceptions of the election outcome over time. The top panel shows the proportion of registered voters that identified Biden as the winner of the 2020 presidential election, and the bottom panel shows the proportion that viewed the election as legitimate. These proportions have stayed relatively fixed over time. Only 3 out of 4 registered American voters believe Joe Biden legitimately won the election. For reference, we also note the major events that occurred throughout the post-election period.

Not surprisingly, there is a sharp partisan divergence in perceptions of the election. Figure presents the same outcomes as Figure 1, this time breaking out the results by party identification. Shortly after the initial election results came in on the evening of November 3rd, most Democrats identified Joe Biden as the winner and perceived the outcome as legitimate. This proportion rose to close to $100 \%$ after the election results were called by most media outlets on November 7th. Republican voters as a group increasingly identified Biden as the winner as the results came in, but this proportion plateaued at around $40 \%$ and remained relatively stable even after the results became certified by the Electoral College and then Congress. Voters that identify as independent or members of other parties appear increasingly accepted the legitimacy of a Biden win as the results came in from different states, but again, this proportion plateaued. Nine days after Joe Biden was sworn in as President, roughly $25 \%$ of 
unaffiliated voters do not view the election as legitimate.

In order to probe whether particular events could effectively challenge the "big lie," from November 16th to December 15th, we asked respondents who identified Trump as the winner a "Yes" or "No" question of the form, "Would you believe that Joe Biden won the election if...", followed by a hypothetical political event. Overall, 1245 respondents, the majority of them Republican (76\%) saw this question over the 11 waves of the survey it was included. The results are presented in Table 1. 
Outcome: Believes Biden Won

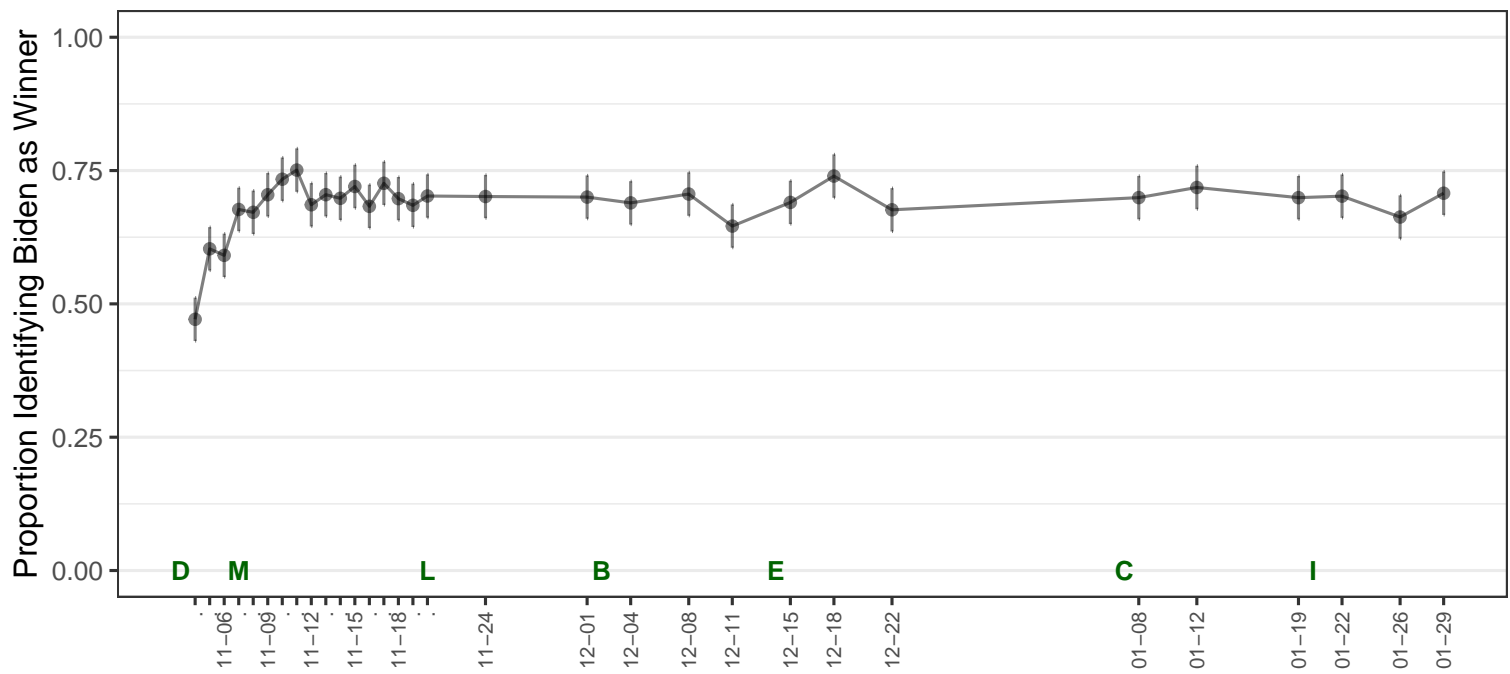

Outcome: Election Result Legitimate

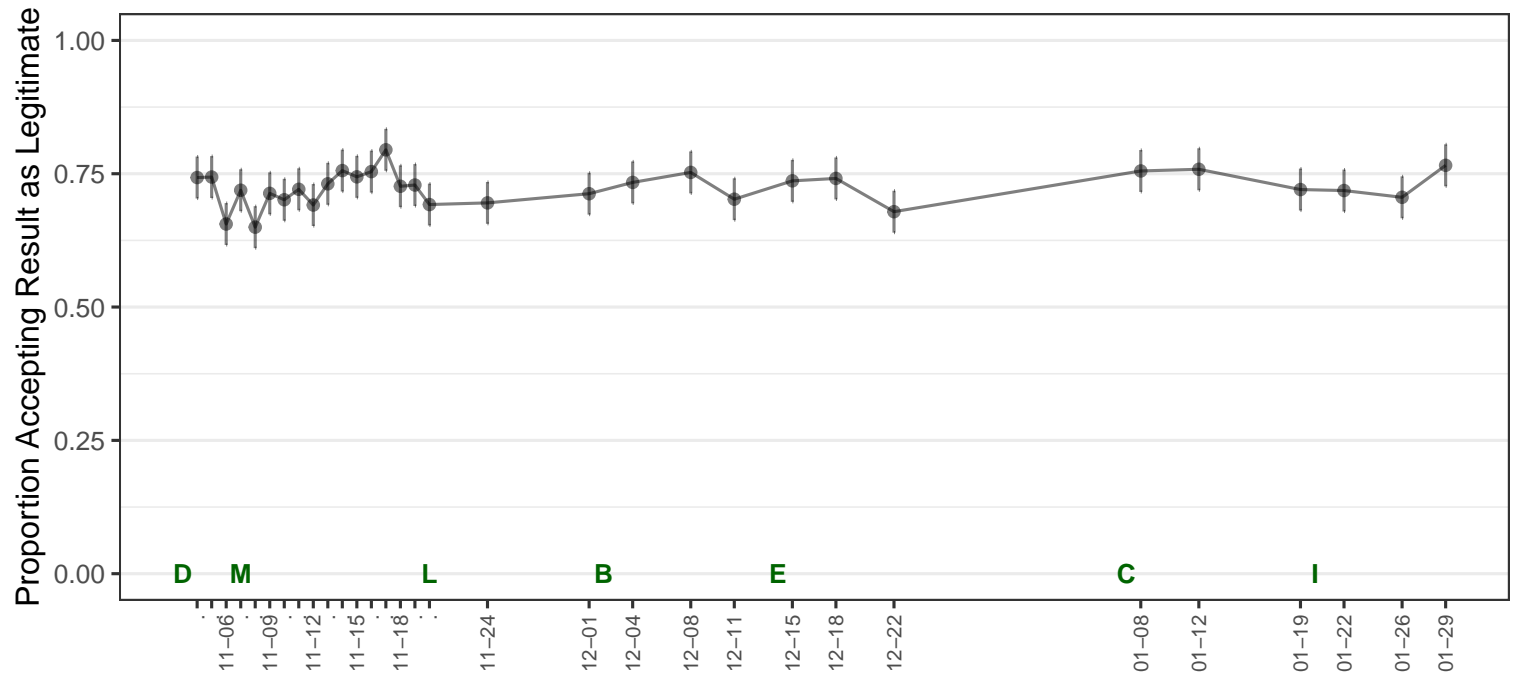

Figure 1: Perceptions of 2020 election outcome. The top panel shows the proportion of respondents that answered "Joe Biden" to the question, "Who do you think won the 2020 presidential election?" The bottom panel shows the proportion that responded "Yes" to the question, "Do you accept the election results as legitimate?" Starting on November 8th, the legitimacy question was preceded by the sentence, "Major news networks have announced that Joe Biden is the winner of the 2020 presidential election." Letters mark significant political events: $\mathrm{D}=$ Election Day, Nov 3; $\mathrm{M}=$ Race called by news networks, Nov 7; L = Trump invites Michigan legislators to White House, Nov 24 ; B = Barr says no evidence of fraud, Dec 2; E = Electoral College certifies Biden, Dec 15; C = Capitol insurrection, Jan 7; I = Inauguration Day, Jan 20. Line segments represent 95\% confidence intervals. All data drawn from Election Legitimacy Tracking Survey (ELTS). 

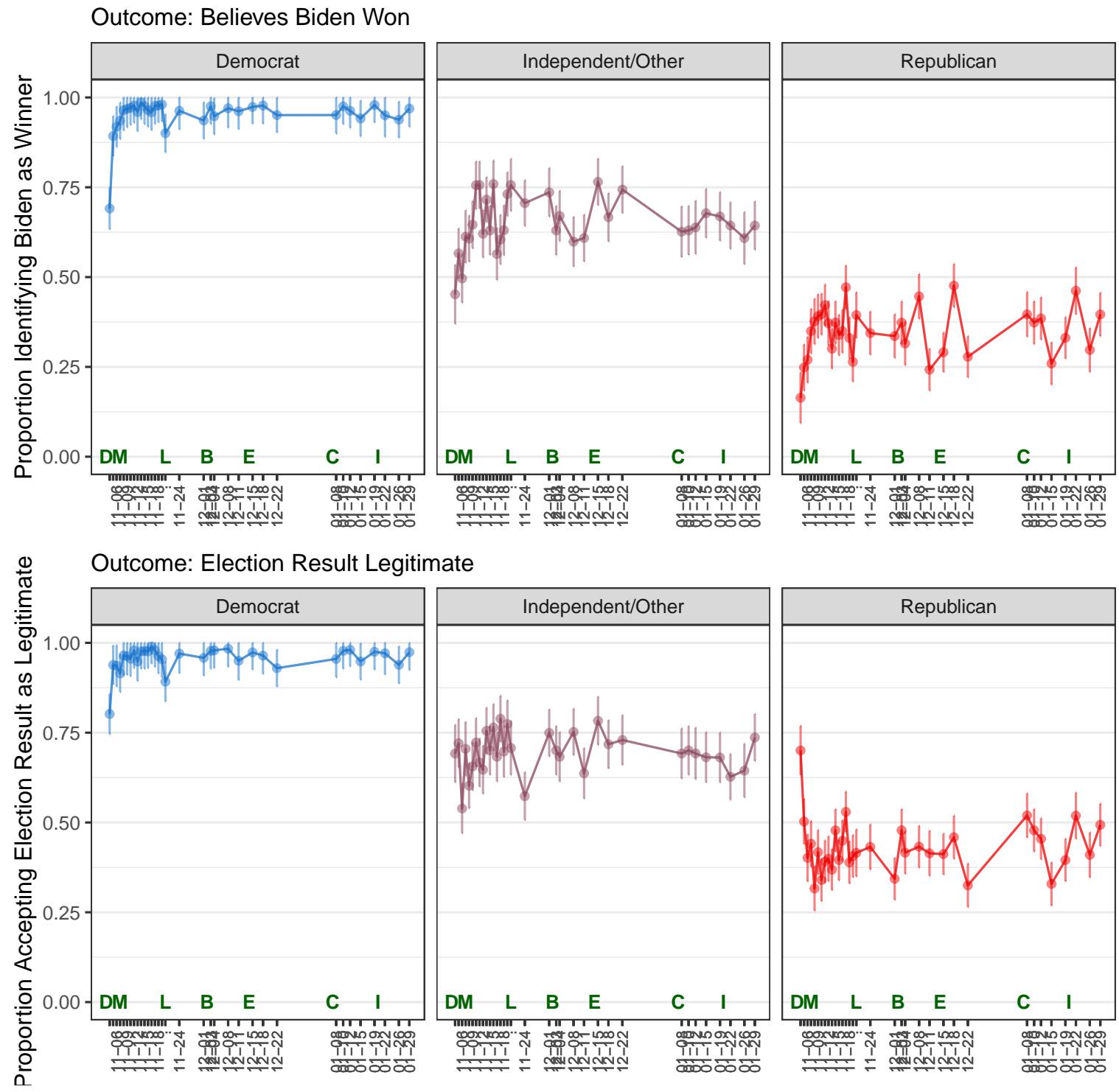

Figure 2: Perceptions of 2020 election outcome by partisanship. The top panel shows the proportion of respondents that answered "Joe Biden" to the question, "Who do you think won the 2020 presidential election?" The bottom panel shows the proportion that responded "Yes" to the question, "Do you accept the election results as legitimate?" Starting on November 8th, the legitimacy question was preceded by the sentence, "Major news networks have announced that Joe Biden is the winner of the 2020 presidential election." Letters mark significant political events: D = Election Day, Nov 3; M = Race called by news networks, Nov 7; L = Trump invites Michigan legislators to White House, Nov $24 ; \mathrm{B}=$ Barr says no evidence of fraud, Dec 2; $\mathrm{E}=$ Electoral College certifies Biden, Dec 15; $\mathrm{C}=$ Capitol insurrection, Jan 7; I = Inauguration Day, Jan 20. Line segments represent 95\% confidence intervals. All data drawn from Election Legitimacy Tracking Survey (ELTS). 
Table 1: What Would It Take to Believe Joe Biden Won

\begin{tabular}{lc}
\hline \hline Would you believe Joe Biden won the election if... & \% Responding "Yes" \\
\hline $\begin{array}{l}\text { a. Republican leaders, such as Senate Majority Leader Mitch Mc- } \\
\text { Connell, say that Joe Biden won more votes than Donald Trump. }\end{array}$ & 28.7 \\
b. The Supreme Court rules that Joe Biden won more votes than & 42.9 \\
Donald Trump. & 30.9 \\
c. The Electoral College awards a majority of votes to Joe Biden. & 26.6 \\
d. The U.S. Congress awards a majority of votes to Joe Biden. & 45.2 \\
e. Donald Trump concedes the election to Joe Biden. & 37.5 \\
f. Joe Biden is sworn in as President by the Chief Justice of the \\
Supreme Court on January $20,2021$.
\end{tabular}

$\mathrm{n}=1245$

Note: Table shows the responses to a question that was shown to respondents who did not identify Joe Biden as the winner of the election even after the race had been called. The question was only included in the survey from November 16th to December 15th. All data drawn from Election Legitimacy Tracking Survey (ELTS).

The data indicate a general reluctance to shift perceptions of the outcome even with new political developments. Of the voters that denied the outcome, $28.7 \%$ said they would believe Biden won if Republican leaders like Mitch McConnell were to say that Biden won more votes. About $31.0 \%$ would believe Biden won if the Electoral College were to award him a majority of votes, and $42.9 \%$ would believe Biden won if there were a Supreme Court decision to that effect. About $45.2 \%$ of people who identified Trump as the winner would believe Biden won if Trump were to concede. About $33 \%$ of respondents who did not view the Biden win as legitimate identified no event that would make them think he actually won.

It is worth noting that as these events actually unfolded, we did not observe equivalent increases in the acceptance of the outcome. In the one month period from November 16th to December 15th, we surveyed 1558 Republican voters, 941 (60.4\%) of which refused to identify Biden as the election winner. Based on this estimate, as well as the data from the 
hypothetical scenarios shown in Table 1, we would have expected about 585 of those voters to have come around by Inauguration Day, yielding an overall acceptance rate of the Biden win among Republican voters at around $76 \%$. The actual proportion continues to hover around $40 \%$, which suggests a certain stickiness to the lie. Voters who bought into Trump's stolen election narrative do not appear to readily update their perceptions of events, even when told by Republican elites to do so, and after Biden formally became president.

Outcome: Election Result Legitimate

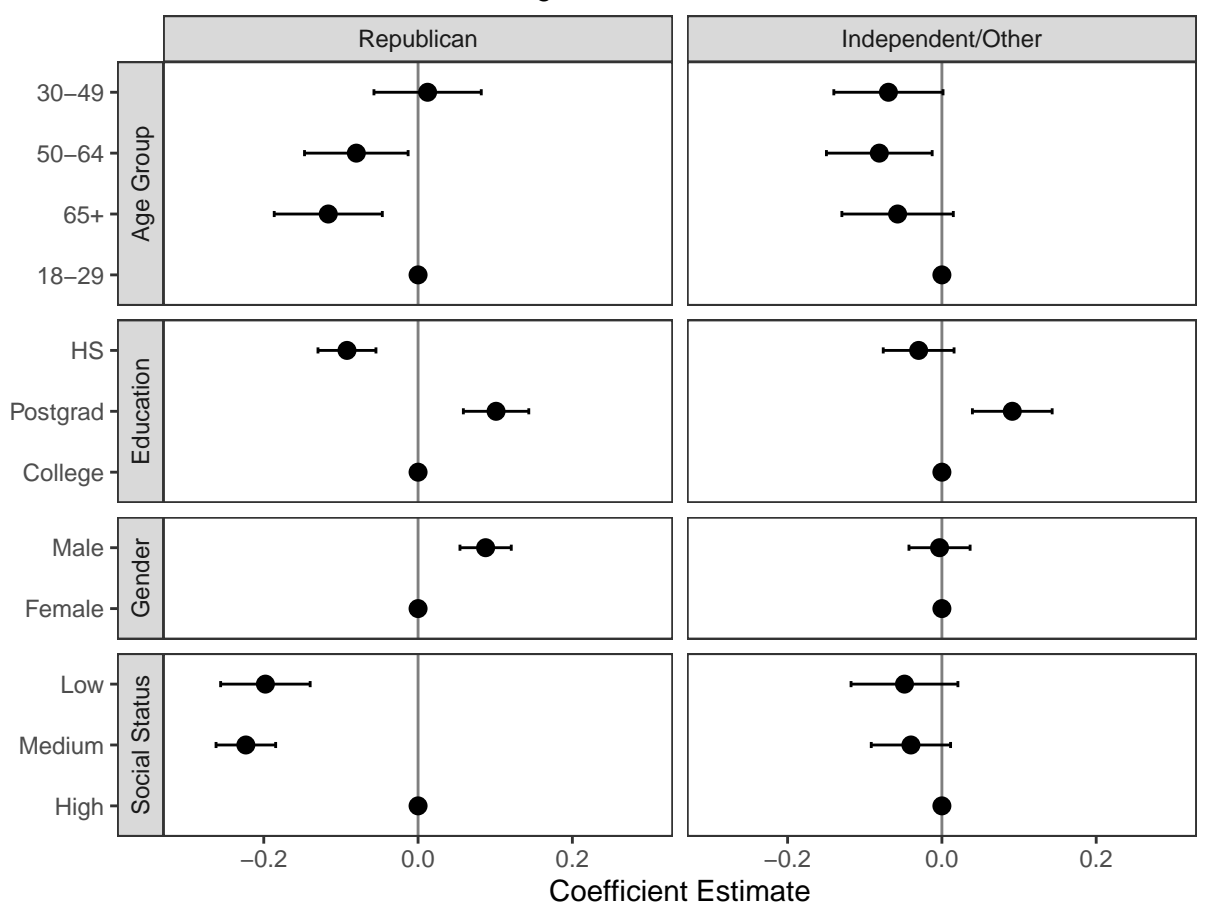

Figure 3: Perceptions of 2020 election outcome by partisanship and demographics. The figure shows the coefficient estimates from a linear probability model where the binary legitimate variable was regressed on demographic covariates of interest. Starting on November 8th, the legitimacy question was preceded by the sentence, "Major news networks have announced that Joe Biden is the winner of the 2020 presidential election" - the estimates in this figure reflect data collected after that date. Line segments represent $95 \%$ confidence intervals. All data drawn from Electoral Legitimacy Tracking Survey (ELTS).

Figure 3 explores who is most likely to reject the election result. The figure presents the results of a simple linear probability model, regressing the binary legitimate variable on demographic covariates of interest. The left panel presents results for Republican voters, and the right panel presents results for voters that identified no partisan affiliation. 
We observe that voters who are older, less educated, and categorize themselves as having lower social status are less likely to perceive the Biden win as legitimate. These relationships hold for both Republican and independent voters, though they are more pronounced among Republican respondents. Independent voters are also much more likely overall to accept the election outcome.

Support for Political Violence

Did the perpetuation of the lie affect support for political violence among the American public? The ELTS core questionnaire included Moskalenko and McCauley (2009)'s Radicalism Intention Scale (RIS), which assesses a respondent's readiness to participate in violent or illegal political action. The questions measure willingness to participate in a violent protest, attack police forces, encourage others to participate in illegal protests, and go to war on behalf of ones social group, among other behaviors (see the Supporting Information for exact question wordings). Respondents were asked their level of agreement on a scale of one to five, and their answers were averaged over the five questions in the battery. Higher scores indicate greater agreement and willingness to participate in violence $(\bar{x}=2.67, S D=1.21)$. 
Outcome: Support for Political Violence

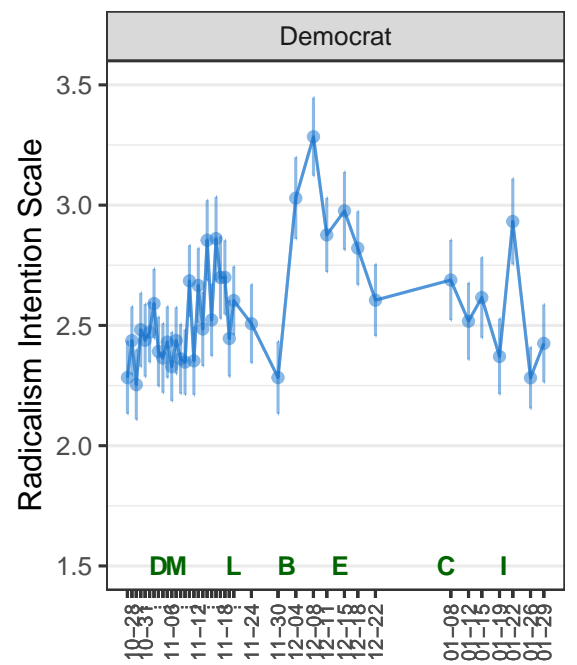

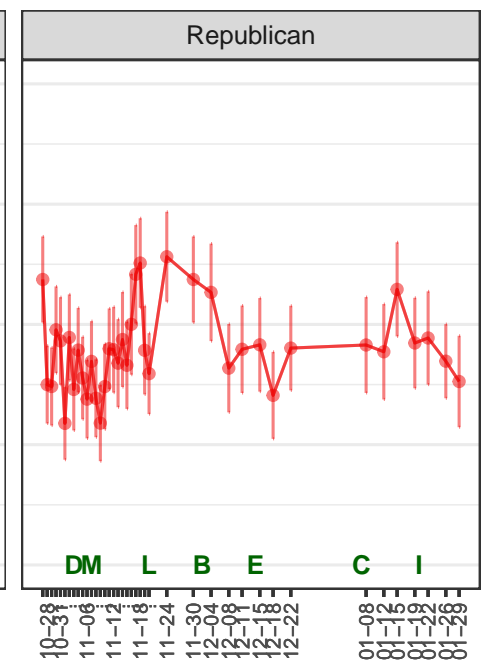

Figure 4: Support for political violence by partisanship. Letters mark significant political events: $\mathrm{D}=$ Election Day, Nov 3; $\mathrm{M}=$ Race called by news networks, Nov 7; L = Trump invites Michigan legislators to White House, Nov $24 ; \mathrm{B}=$ Barr says no evidence of fraud, Dec 2; E = Electoral College certifies Biden, Dec 15; C = Capitol insurrection, Jan 7; I = Inauguration Day, Jan 20. Line segments represent 95\% confidence intervals. All data drawn from Election Legitimacy Tracking Survey (ELTS).

Figure 4 shows the evolution of support for political violence over time, again disaggregating the data by partisanship. ${ }^{3}$ We observe higher levels of support for violence among partisans, and a quite noticeable increase in support for violence among Democrats in the immediate aftermath of the election. This support peaked just before the Electoral College members cast their votes on December 14th, perhaps in response to Trump's public efforts to pressure local officials and legislators to dismiss votes from key states. Put differently, Trump's perpetuation of the lie, coupled with his attempts to actually overturn the election result, appear to have pushed Democratic voters into a more violent mindset. This mindset subsided substantially after the election result was secured by the Electoral College vote and the events of January 6th, but support for violence among Democrats remained significantly higher than pre-election levels even after Biden was inaugurated.

Table 2 shows this more systematically. It presents the results of a regression of the RIS variable on different event indicators of interest. This allows us to see how specific events ${ }^{3}$ Figure in the Supporting Information shows the aggregate results. 
Table 2: Effects of 2020 Election Events on Support for Political Violence

\begin{tabular}{|c|c|c|c|c|}
\hline \multirow[t]{2}{*}{ Event } & \multicolumn{4}{|c|}{ Estimates } \\
\hline & Overall & Republicans & Democrats & Ind/Other \\
\hline Pre-election (Intercept) & $\begin{array}{c}2.32 \\
(0.018)\end{array}$ & $\begin{array}{c}2.36 \\
(0.033)\end{array}$ & $\begin{array}{c}2.43 \\
(0.029)\end{array}$ & $\begin{array}{c}2.08 \\
(0.033)\end{array}$ \\
\hline + Post Election Day (Nov 3) & $\begin{array}{l}-0.030 \\
(0.032)\end{array}$ & $\begin{array}{l}-0.055 \\
(0.057)\end{array}$ & $\begin{array}{l}-0.032 \\
(0.050)\end{array}$ & $\begin{array}{l}0.0051 \\
(0.057)\end{array}$ \\
\hline + Post Election Call (Nov 7) & $\begin{array}{c}0.150 \\
(0.030)\end{array}$ & $\begin{array}{c}0.117 \\
(0.052)\end{array}$ & $\begin{array}{c}0.190 \\
(0.046)\end{array}$ & $\begin{array}{c}0.116 \\
(0.053)\end{array}$ \\
\hline + Post Trump Invite MI Legislators (Nov 20) & $\begin{array}{c}-0.036 \\
(0.054)\end{array}$ & $\begin{array}{l}-0.165 \\
(0.096)\end{array}$ & $\begin{array}{c}0.221 \\
(0.084)\end{array}$ & $\begin{array}{l}-0.315 \\
(0.096)\end{array}$ \\
\hline + Post Barr Citing No Fraud (Dec 2) & $\begin{array}{c}0.294 \\
(0.060)\end{array}$ & $\begin{array}{c}0.195 \\
(0.107)\end{array}$ & $\begin{array}{l}0.254 \\
0.094\end{array}$ & $\begin{array}{l}0.525 \\
0.108\end{array}$ \\
\hline + Post Electoral College (Dec 14) & $\begin{array}{l}-0.165 \\
(0.043)\end{array}$ & $\begin{array}{l}-0.109 \\
(0.076)\end{array}$ & $\begin{array}{c}-0.256 \\
0.067\end{array}$ & $\begin{array}{c}-0.151 \\
0.078\end{array}$ \\
\hline+ Post Insurrection (Jan 6) & $\begin{array}{l}-0.109 \\
(0.043)\end{array}$ & $\begin{array}{c}0.068 \\
(0.076)\end{array}$ & $\begin{array}{l}-0.275 \\
(0.066)\end{array}$ & $\begin{array}{l}-0.039 \\
(0.080)\end{array}$ \\
\hline + Post Inauguration (Jan 20) & $\begin{array}{c}-0.039 \\
(0.042)\end{array}$ & $\begin{array}{l}-0.057 \\
(0.076)\end{array}$ & $\begin{array}{l}-0.003 \\
(0.066)\end{array}$ & $\begin{array}{l}-0.035 \\
(0.078)\end{array}$ \\
\hline Cumulative Effect & $\begin{array}{c}0.126 \\
(0.021)\end{array}$ & $\begin{array}{c}0.029 \\
(0.037)\end{array}$ & $\begin{array}{c}0.197 \\
(0.033)\end{array}$ & $\begin{array}{c}0.120 \\
(0.037)\end{array}$ \\
\hline $\mathrm{n}$ & 19,175 & 6,407 & 8,401 & 4,115 \\
\hline
\end{tabular}

Note: Table shows coefficient estimates from regressions of political violence scale on event indicators.

Standard errors shown in parentheses. All data drawn from Election Legitimacy Tracking Survey (ELTS).

moved support for political violence, as well as the cumulative effect of the full election cycle from November through January. We observe that by mid December, support for political violence among Democrats had risen by about 0.633 points on a five point scale, about half of a standard deviation. The Electoral College vote and the events of January 6th in turn dampened support for violence by about 0.254 and 0.201 points respectively. The cumulative 
effect size of the election for Democrats was about 0.216 , a little less than one fifth of a standard deviation.

Figure 7 explores precisely which members of the American population believe political violence is most justified. As before, the results are disaggregated by partisanship, but the relationships that emerge are actually the same for Democrats, Republicans, and unaffiliated voters. We observe that voters that are younger, male, more educated, and higher social status are more likely to cite that violence is justified.

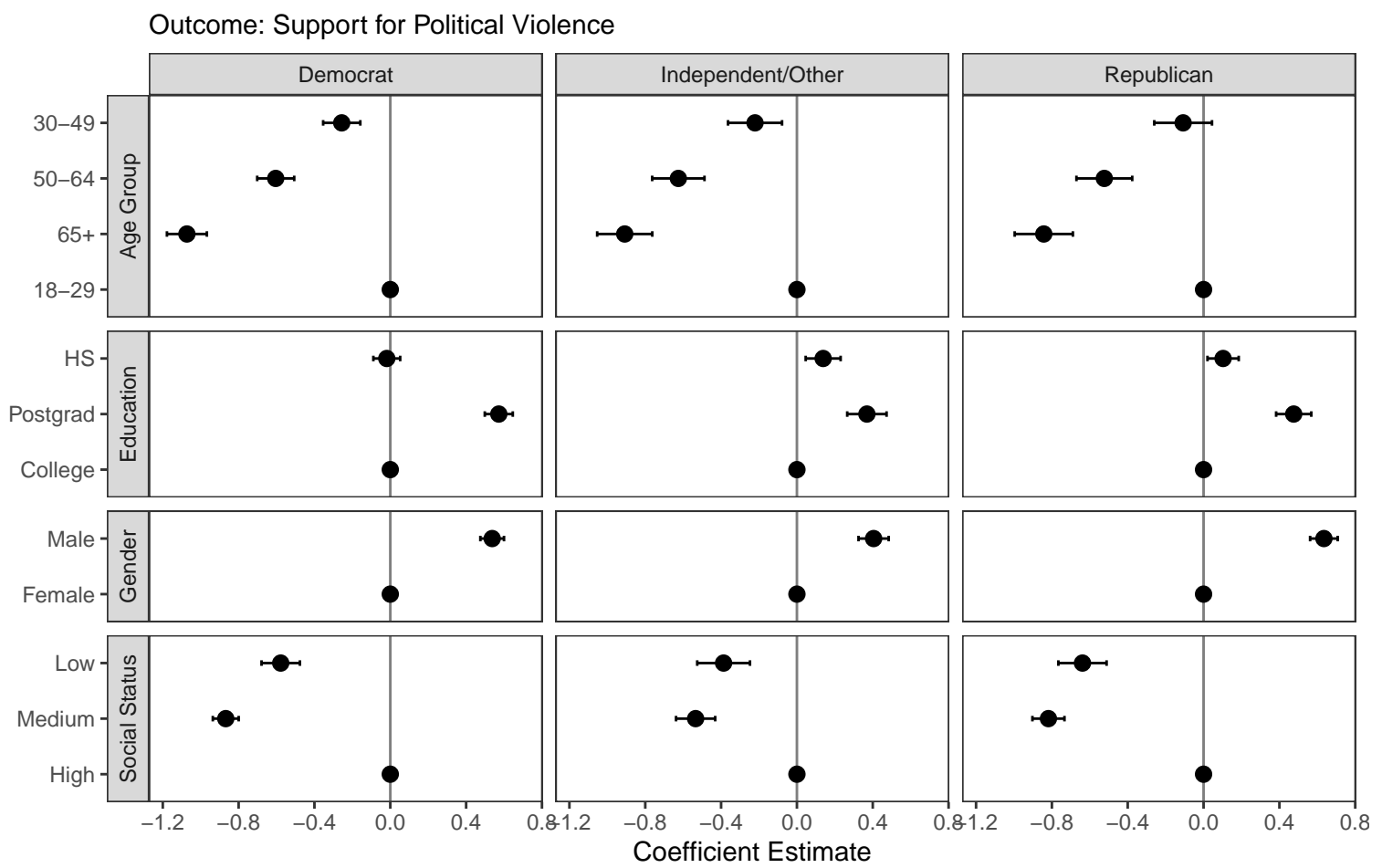

Figure 5: Support for political violence by partisanship and demographics. The figure shows the coefficient estimates from a linear model where the political violence was regressed on demographic covariates of interest. The estimates in this figure reflect data collected after November 8th. Line segments represent 95\% confidence intervals. All data drawn from Electoral Legitimacy Tracking Survey (ELTS). 


\section{Identity}

To what extent did voters de-identify with Donald Trump as the election outcome unfolded, and the lie itself was rebuked by the media, courts, and other political elites? The ELTS questionnaire a two question battery that measurement respondent's degree to which they felt praise or insults of their candidate at a personal level. These questions averaged to create a simple candidate identification index, with higher values indicating greater affective attachment with the candidate $(\bar{x}=3.69, S D=1.03)$.

Figure 6 shows the mean values of this variable over time for Democrats and Republicans, which evaluated their identification with Biden and Trump, respectively. Table 3 shows the regression results, again utilizing the time period indicators as before. 


\section{Outcome: Biden Identification, Sample: Democrats}

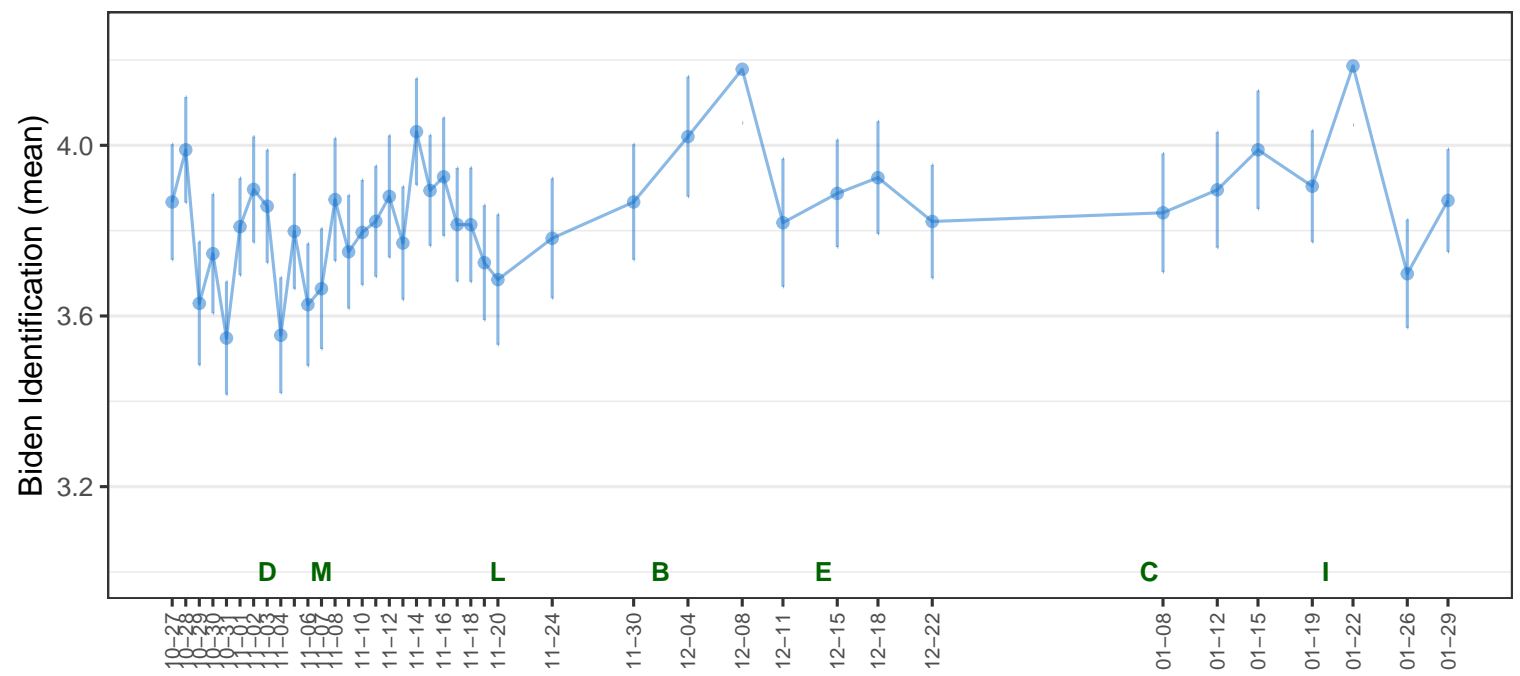

Outcome: Trump Identification, Sample: Republicans

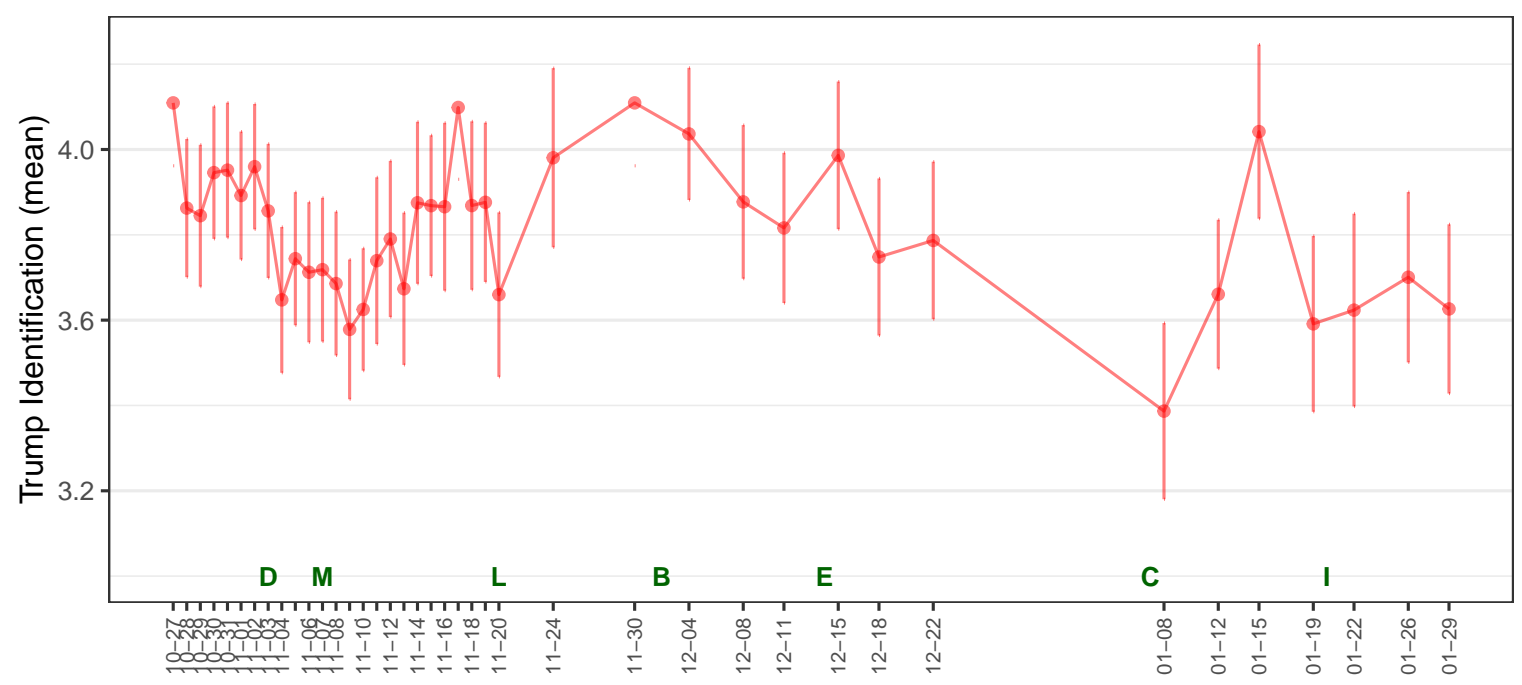

Figure 6: Candidate identification by partisanship. Letters mark significant political events: D = Election Day, Nov 3; $\mathrm{M}=$ Race called by news networks, Nov 7; L = Trump invites Michigan legislators to White House, Nov 24; B = Barr says no evidence of fraud, Dec 2; E = Electoral College certifies Biden, Dec 15; C = Capitol insurrection, Jan 7; I = Inauguration Day, Jan 20. Line segments represent $95 \%$ confidence intervals. All data drawn from Election Legitimacy Tracking Survey (ELTS)..

Among Democrats, we observe a very small cumulative effect of the election result on identification with Biden, about 0.042 points on a five point scale over the 2.5 month period of the study. This might be in part because of a ceiling effect; identification with Biden was already very high prior to the election (3.79 on a 5 point scale). The Biden identification index 
did increase substantially following the election being called by media outlets on November 7, and it peaked on the day following his inauguration.

Among Trump voters, we observe some limited evidence of deidentification. Prior the election, Trump voters expressed higher levels of identification with him (3.93) than Democrats did for Biden. This decreased after election night (-.221) but rebounded after the race had been called on November 7 and Trump continued to contest the result. Identification with Trump reached its nadir in the Friday after the capitol insurrection, but then rebounded to pre-election levels just a week later. After Biden was Inaugurated, Trump identification stood about .172 points lower than it had prior to the election, a real but not seismic shift. 
Table 3: Effects of 2020 Election Events on Identification with Candidate

\begin{tabular}{|c|c|c|}
\hline \multirow[t]{2}{*}{ Event } & \multicolumn{2}{|c|}{ Estimates } \\
\hline & $\begin{array}{l}\text { Republicans } \\
\text { (Trump ID) }\end{array}$ & $\begin{array}{l}\text { Democrats } \\
\text { (Biden ID) }\end{array}$ \\
\hline Pre-election (Intercept) & $\begin{array}{c}3.93 \\
(0.018)\end{array}$ & $\begin{array}{c}3.79 \\
(0.023)\end{array}$ \\
\hline + Post Election Day (Nov 3) & $\begin{array}{c}-0.221 \\
(0.05160)\end{array}$ & $\begin{array}{c}-0.13 \\
(0.041680)\end{array}$ \\
\hline + Post Election Call (Nov 7) & $\begin{array}{c}0.086 \\
(0.049)\end{array}$ & $\begin{array}{c}0.17 \\
(0.039)\end{array}$ \\
\hline + Post Trump Invite MI Legislators (Nov 20) & $\begin{array}{l}-0.101 \\
(0.086)\end{array}$ & $\begin{array}{l}-0.064 \\
(0.072)\end{array}$ \\
\hline + Post Barr Citing No Fraud (Dec 2) & $\begin{array}{c}0.221 \\
(0.096)\end{array}$ & $\begin{array}{c}0.247 \\
(0.081)\end{array}$ \\
\hline + Post Electoral College (Dec 14) & $\begin{array}{l}-0.076 \\
(0.071)\end{array}$ & $\begin{array}{l}-0.131 \\
(0.057)\end{array}$ \\
\hline+ Post Insurrection (Jan 6) & $\begin{array}{l}-0.286 \\
(0.071)\end{array}$ & $\begin{array}{c}0.003 \\
(0.056)\end{array}$ \\
\hline + Post Inauguration (Jan 20) & $\begin{array}{c}0.100 \\
(0.071)\end{array}$ & $\begin{array}{c}0.017 \\
(0.056)\end{array}$ \\
\hline Cumulative Effect & $\begin{array}{l}-0.172 \\
(0.033)\end{array}$ & $\begin{array}{c}0.042 \\
(0.027)\end{array}$ \\
\hline $\mathrm{n}$ & 5,060 & 7,292 \\
\hline
\end{tabular}

Note: Table shows coefficient estimates from regressions of candidate identification scale on event indicators. Standard errors shown in parentheses. All data drawn from Election Legitimacy Tracking Survey (ELTS). 


\section{Electoral Consequences}

To what extent will Trump's "big lie" continue to affect American politics moving forward? Trump narrowly escaped impeachment for his conduct during the insurrection of January 6th. This vote proved contentious for Republican legislators, and those that did vote to impeach were rebuked by other members of the party.

To assess the electoral consequences of the lie, we included a "paired conjoint" experiment on the ELTS questionnaire beginning on January 12 (Hainmueller, Hopkins and Yamamoto 2014; Hainmueller, Hangartner and Yamamoto 2015; Teele, Kalla and Rosenbluth 2018). The conjoint questions asked Republican and Independent respondents to imagine a hypothetical Republican congressional primary race, presenting them with a choice of two candidates. Respondents then viewed a table of two candidate profiles with randomly assigned attributes like profession, age, ethnicity, and gender. We varied whether the candidate took a position on the outcome of the 2020 election: Either they believed that Biden won and would have certified the result for him, or they believed that Trump won and would have not voted to certify the election for Biden. Figure SI6 in the Supporting Information shows how the profiles appeared in the survey. Respondents evaluated three pairs of candidates each.

Because these attributes were randomly assigned, we can recover the average marginal component effect (AMCE) of the attribute on selection for political office using a simple linear regression, clustering the standard errors at the respondent level (Hainmueller, Hopkins and Yamamoto 2014). After accounting for profession, religion, gender and so on, a candidate who asserts that Trump really won the 2020 election did better than those who say that Trump lost. Among Republican respondents, on average, a "Trump won" candidate is favored by six percentage points against the opponent. This suggests the lie will have real staying power in American politics, at least for the next election cycle, when it could become a issue that divides Republican primary candidates. 


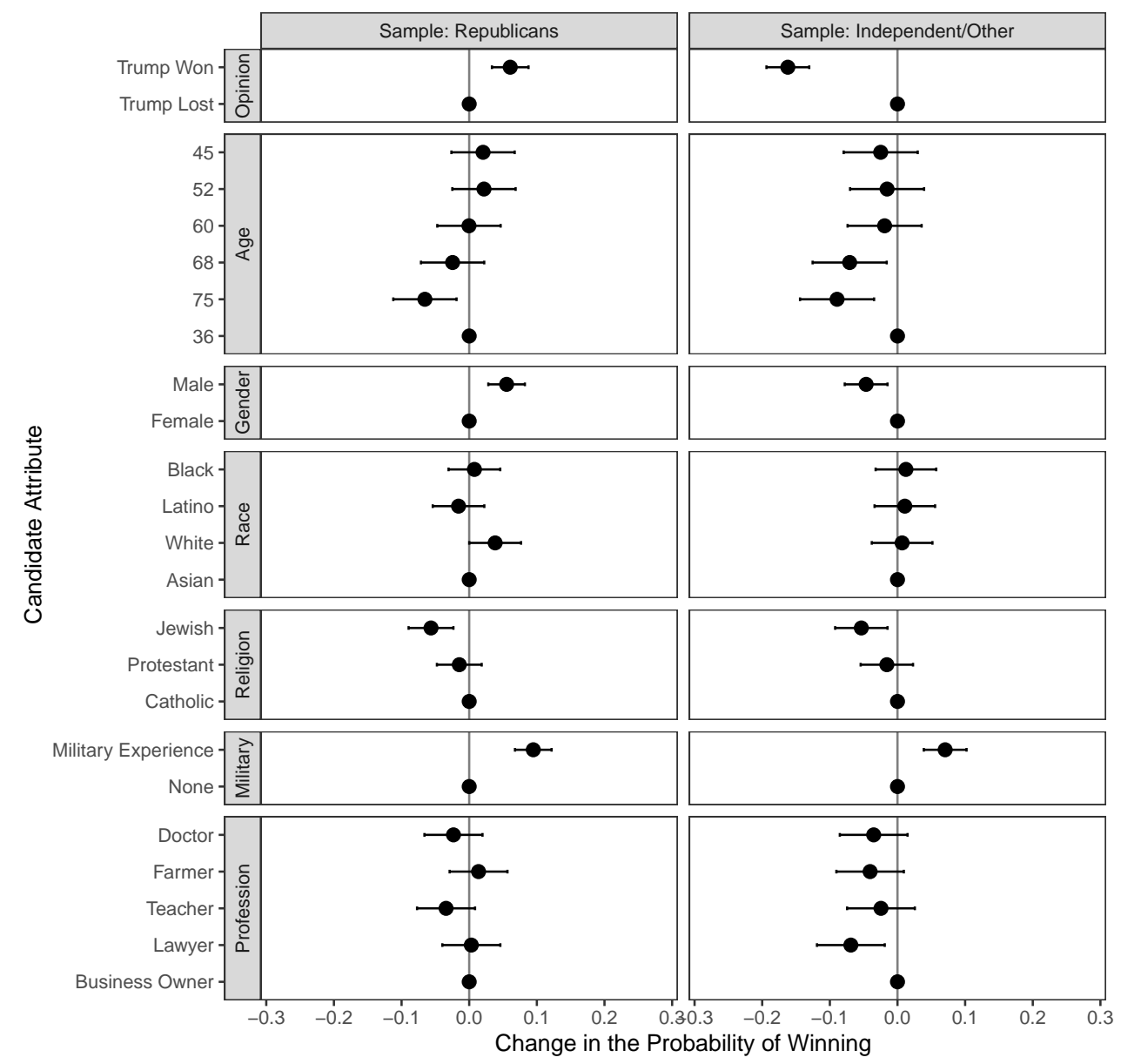

Figure 7: Results of conjoint experiment. The figure shows the coefficient estimates from a linear model where the candidate choice outcome was regressed on the randomly assigned candidate attributes in the conjoint experiment. The estimates in this figure reflect data collected after January 12th. Line segments represent $95 \%$ confidence intervals, which reflect standard errors clustered at the respondent level. All data drawn from Electoral Legitimacy Tracking Survey (ELTS). 


\section{Discussion}

Our study systematically documents a new feature of American political life- roughly one fourth of the country, and half of the Republican Party, buys into the idea that the election was somehow stolen from Trump. This "big lie" is pervasive, sticky, and consequential.

The steady rise in polarization between the Democratic and Republicans parties over the past 30 years (McCarty 2019) has stoked growing hostility between partisans (Iyengar, Sood and Lelkes 2012), led to a tighter fusion between partisan and other important social identities (Mason 2018. When voters identify as belonging to a political party, many come to categorize other members of their party as "us" and members of opposing parties as "they" (Huddy, Mason and Aarøe 2015).

People draw self-esteem for being a part of groups that compare favorably to other groups (Hirt et al. 1992; Tajfel and Turner 1979). We know that in the face of victory or defeat, individuals will adopt differing cognitive strategies in order to preserve their self-concept. Psychologists have identified a behavioral pattern known as "bask(ing) in reflected glory" (BIRGing), which is the tendency to take credit for the accomplishments of someone else and publicize one's association with that person. In the well-known "Three (Football) Field Study", Cialdini et al. (1976) show that students had a greater tendency to wear their school's apparel after a football team victory than a defeat, and are more likely to use the word "we" when describing a win than a loss. In a related set of experiments, Hirt et al. (1992), show that after observing their team win, fans have higher levels of self-esteem and enhanced performance on certain cognitive tasks. Partisan ties in democracies may operate through similar identity-based mechanisms (Greene 2004). After elections in Belgium, researchers found that citizens kept up their candidate lawn signs longer if their candidate had won than if she had lost (Boen et al. 2002). The opposite tendency is known as CORFing- cutting off reflecting failure. People dissociate themselves with perceived losers as a way to manage their own identities and self-concepts (Hirt et al. 1992; Boen et al. 2002). 
For this reason, elections in democracies can create a certain cognitive dissonance and threaten the self-concept of members of the losing side. Typically we would expect individuals to de-identify with the losing candidate- "I never really liked that guy anyway" - in turn insulating themselves from the loss. But in the 2020 presidential election, the presence of a "big lie" about election fraud presented Republican voters with an attractive alternativereject the loss itself. This sort of outcome denial is usually a cognitive strategy for some voters on the losing side (Alvarez, Hall and Llewellyn 2008; Anderson et al. 2005; Sances and Stewart 2015), but the fact that this narrative was proffered by the president and many Republican elites rendered it more socially acceptable and pervasive. Rather than cut themselves off from Trump and the failure of a lost election, many Republicans have chosen instead to cut themselves off from reality. 


\section{References}

Almond, Gabriel Abraham and Sidney Verba. 1963. The civic culture: Political attitudes and democracy in five nations. Boston: Little, Brown, and Company.

Alvarez, R. Michael, Thad E Hall and Morgan H Llewellyn. 2008. "Are Americans Confident Their Ballots Are Counted?" The Journal of Politics 70(3):754-766.

Anderson, Christopher, Andr\{'e Blais, Shaun Bowler, Todd Donovan and Ola Listhaug. 2005. Loser's Consent: Elections and Democratic Legitimacy. Oxford University Press.

Baron, Jonathan and John C Hershey. 1988. "Outcome bias in decision evaluation." Journal of Personality and Social Psychology 54(4):569.

Boas, Taylor C, Dino P Christenson and David M Glick. 2020. "Recruiting large online samples in the United States and India: Facebook, mechanical turk, and qualtrics." Political Science Research and Methods 8(2):232-250.

Boen, Filip, Norbert Vanbeselaere, Mario Pandelaere, Siegfried Dewitte, Bart Duriez, Boris Snauwaert, Jos Feys, Vicky Dierckx and Eddy Van Avermaet. 2002. "Politics and basking-in-reflected-glory: A field study in Flanders." Basic and Applied Social Psychology $24(3): 205-214$.

Brazeal, Gregory. 2011. "How Much Does a Belief Cost: Revisiting the Marketplace of Ideas." Southern California Interdisciplinary Law Journal 21(1):2-10.

Cantú, Francisco and Omar García-Ponce. 2015. "Partisan losers' effects: Perceptions of electoral integrity in Mexico." Electoral Studies 39:1-14.

Chong, Dennis and James N Druckman. 2007. "Framing public opinion in competitive democracies." American Political Science Review 101(4):637-655. 
Cialdini, Robert B, Richard J Borden, Avril Thorne, Marcus Randall Walker, Stephen Freeman and Lloyd Reynolds Sloan. 1976. "Basking in reflected glory: Three (football) field studies." Journal of personality and social psychology 34(3):366.

Dahl, Robert A. 1989. Democracy and Its Critics. New Have, CT: Yale University Press.

Druckman, James N, Erik Peterson and Rune Slothuus. 2013. "How elite partisan polarization affects public opinion formation." American Political Science Review 107(1):57-79.

Finkel, Eli J, Christopher A Bail, Mina Cikara, Peter H Ditto, Shanto Iyengar, Samara Klar, Lilliana Mason, Mary C McGrath, Brendan Nyhan, David G Rand et al. 2020. "Political sectarianism in America." Science 370(6516):533-536.

Greene, Steven. 2004. "Social identity theory and party identification." Social Science Quarterly 85(1):136-153.

Hainmueller, Jens. 2012. "Entropy balancing for causal effects: A multivariate reweighting method to produce balanced samples in observational studies." Political analysis pp. 25-46.

Hainmueller, Jens, Daniel J Hopkins and Teppei Yamamoto. 2014. "Causal inference in conjoint analysis: Understanding multidimensional choices via stated preference experiments." Political analysis 22(1):1-30.

Hainmueller, Jens, Dominik Hangartner and Teppei Yamamoto. 2015. "Validating vignette and conjoint survey experiments against real-world behavior." Proceedings of the National Academy of Sciences 112(8):2395-2400.

Havel, Vaclav. 2018. "The power of the powerless." East European Politics and Societies $32(2): 353-408$.

Hirt, Edward R, Dolf Zillmann, Grant A Erickson and Chris Kennedy. 1992. "Costs and benefits of allegiance: Changes in fans' self-ascribed competencies after team victory versus defeat." Journal of personality and social psychology 63(5):724. 
Huang, Haifeng. 2015. "Propaganda as signaling." Comparative Politics 47(4):419-444.

Huddy, Leonie, Lilliana Mason and Lene Aarøe. 2015. "Expressive partisanship: Campaign involvement, political emotion, and partisan identity." American Political Science Review 109:1-17.

Huntington, Samuel P. 1991. "Democracy's Third Wave." Journal of Democracy 2(2):12-34.

Inglehart, Ronald. 2003. "How solid is mass support for democracy: And how can we measure it?" PS: Political Science and Politics 36(1):51-57.

Iyengar, Shanto, Gaurav Sood and Yphtach Lelkes. 2012. "Affect, Not Ideology: A Social Identity Perspective on Polarization." Public Opinion Quarterly 76(3):405-431.

Kennedy, Courtney, Mark Blumenthal, Scott Clement, Joshua D Clinton, Claire Durand, Charles Franklin, Kyley McGeeney, Lee Miringoff, Kristen Olson, Douglas Rivers et al. 2018. "An evaluation of the 2016 election polls in the United States." Public Opinion Quarterly 82(1):1-33.

Kuran, Timur. 1991. "Now out of never: The element of surprise in the East European revolution of 1989." World Politics: A Quarterly Journal of International Relations pp. 748.

Mason, Lilliana. 2018. Uncivil Disagreement: How Politics Became Our Identity. Cambridge: University of Chicago Press.

McCarty, Nolan. 2019. Polarization: What Everyone Needs to Know. Oxford University Press.

Moskalenko, Sophia and Clark McCauley. 2009. "Measuring political mobilization: The distinction between activism and radicalism." Terrorism and political violence 21(2):239260. 
Petersen, Michael Bang, Mathias Osmundsen and Kevin Arceneaux. 2018. "A "need for chaos" and the sharing of hostile political rumors in advanced democracies.".

Przeworski, Adam. 1991. Democracy and the market: Political and economic reforms in Eastern Europe and Latin America. Cambridge: Cambridge University Press.

Przeworski, Adam. 2005. "Democracy as an Equilibrium." Public Choice 123(3-4):253-273.

Przeworski, Adam. 2019. Crises of Democracy. Cambridge: Cambridge University Press.

Sances, Michael W and Charles III Stewart. 2015. "Partisanship and confidence in the vote count: Evidence from U.S. national elections since 2000.” Electoral Studies 40(c):176-188.

Schedler, Andreas. 2001. "Measuring Democratic Consolidation." Studies in Comparative International Development 36(1):66-92.

Schmitt, David P and Jüri Allik. 2005. "Simultaneous administration of the Rosenberg SelfEsteem Scale in 53 nations: exploring the universal and culture-specific features of global self-esteem." Journal of personality and social psychology 89(4):623.

Shen, Xiaoxiao and Rory Truex. 2020. "In search of self-censorship." British Journal of Political Science pp. 1-13.

Tajfel, Henri and John C Turner. 1979. An integrative theory of intergroup conflict. In Organizational Identity: A Reader, ed. Mary Jo Hatch and Majken Schultz. Oxford: Oxford University Press pp. 56-65.

Teele, Dawn Langan, Joshua Kalla and Frances Rosenbluth. 2018. "The ties that double bind: social roles and women's underrepresentation in politics." American Political Science Review 112(3):525-541.

Van Bavel, Jay J and Andrea Pereira. 2018. "The partisan brain: An identity-based model of political belief." Trends in Cognitive Sciences 22(3):213-224. 
Wedeen, Lisa. 2015. Ambiguities of domination: Politics, rhetoric, and symbols in contemporary Syria. University of Chicago Press.

Zaller, John R. 1992. The Nature and Origins of Mass Opinion. Cambridge: Cambridge University Press.

Zigmond, Anthony S and R Philip Snaith. 1983. "The hospital anxiety and depression scale." Acta psychiatrica scandinavica 67(6):361-370. 


\section{Supporting Information}

The Supporting Information contains the following:

Figures SI1 and SI2: Sample Composition Over Time

Figure SI3: Perceptions of 2020 election outcome (unweighted data)

Figure SI4: Perceptions of 2020 election outcome by partisanship and demographics (unweighted data)

Figure SI5: Support for Political Violence

Figure SI6: Paired Conjoint Experiment Prompt

Question Wording 

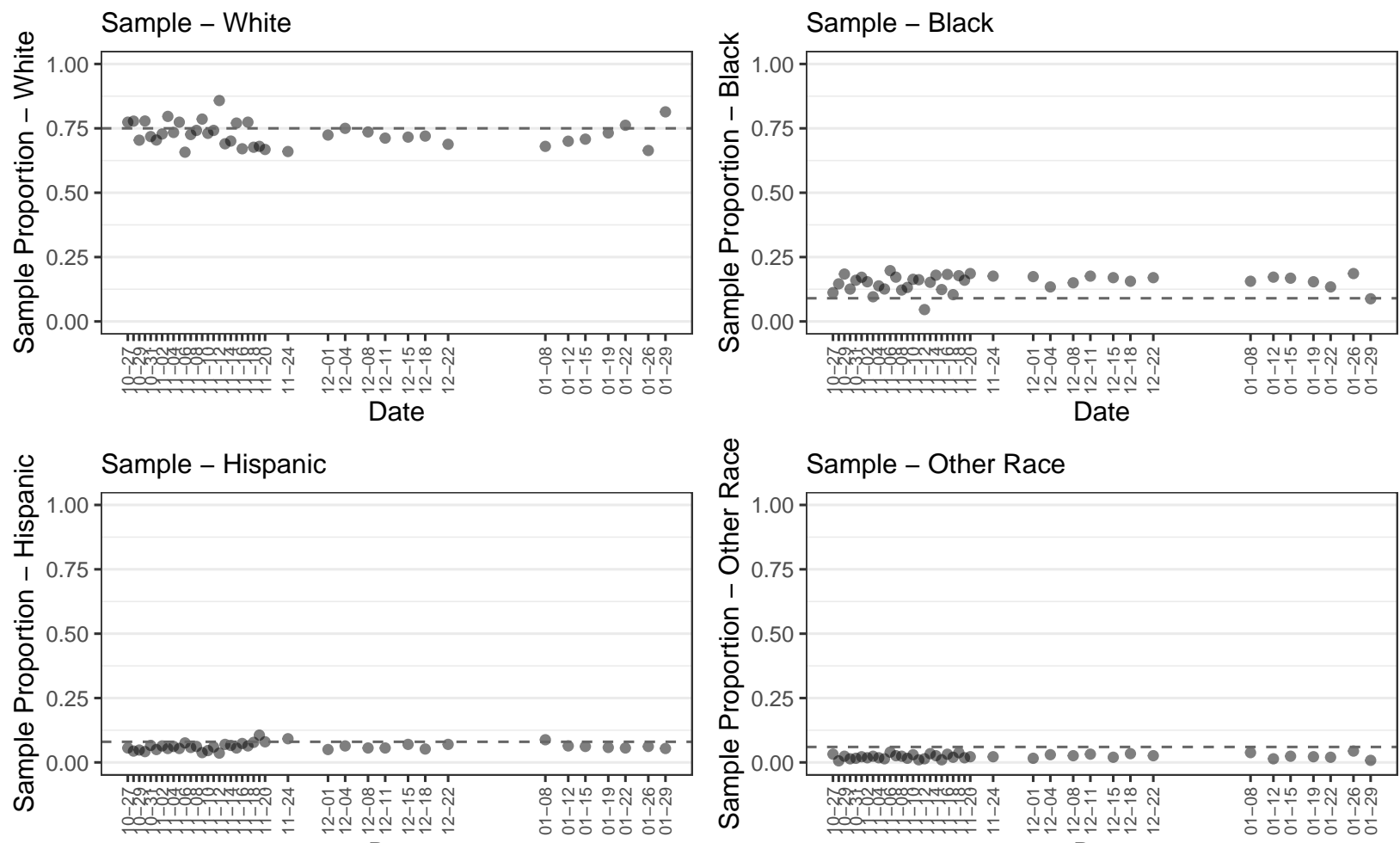

Date
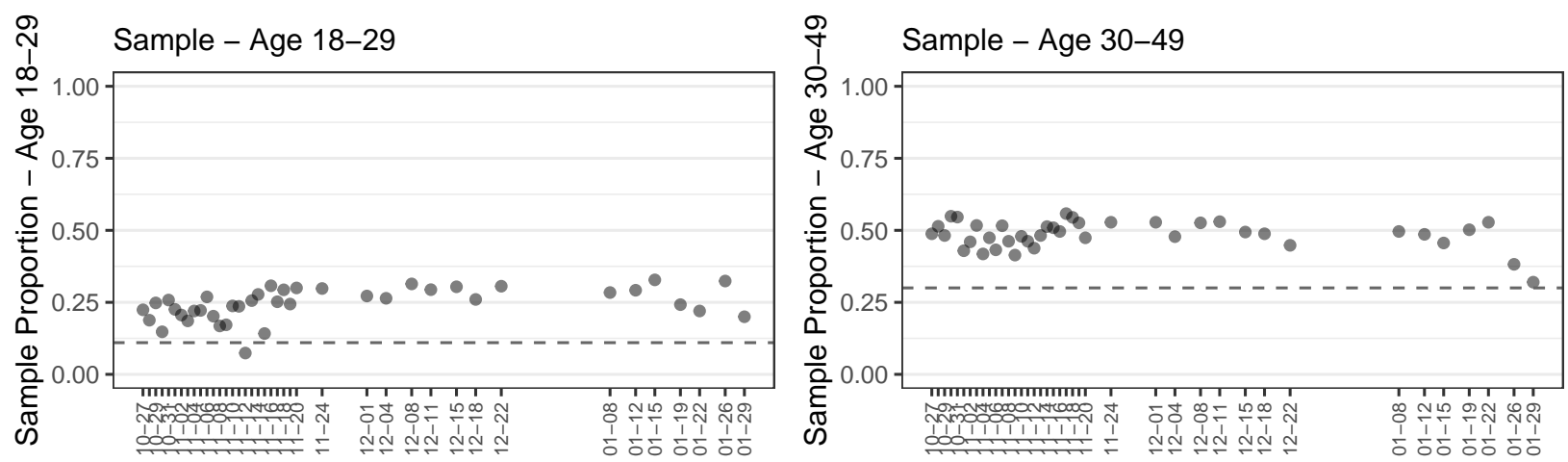

Date
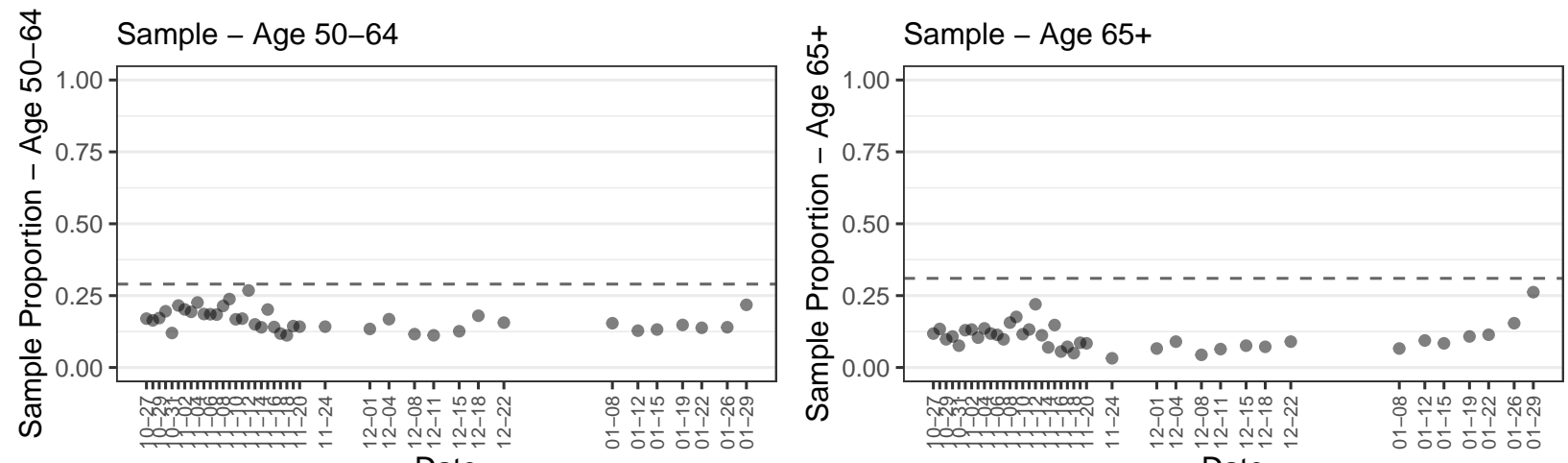

Date

Date

Figure SI1: Sample Composition Over Time (1/2). The figure shows different the share of respondents falling into different demographic categories in each daily sample. The dotted line represents the group's share of registered voters. Categories where the points consistently fall above the dotted line are over-represented in the unweighted survey data. Categories where the points fall below are under-represented. All data drawn from Election Legitimacy Tracking Survey (ELTS). 

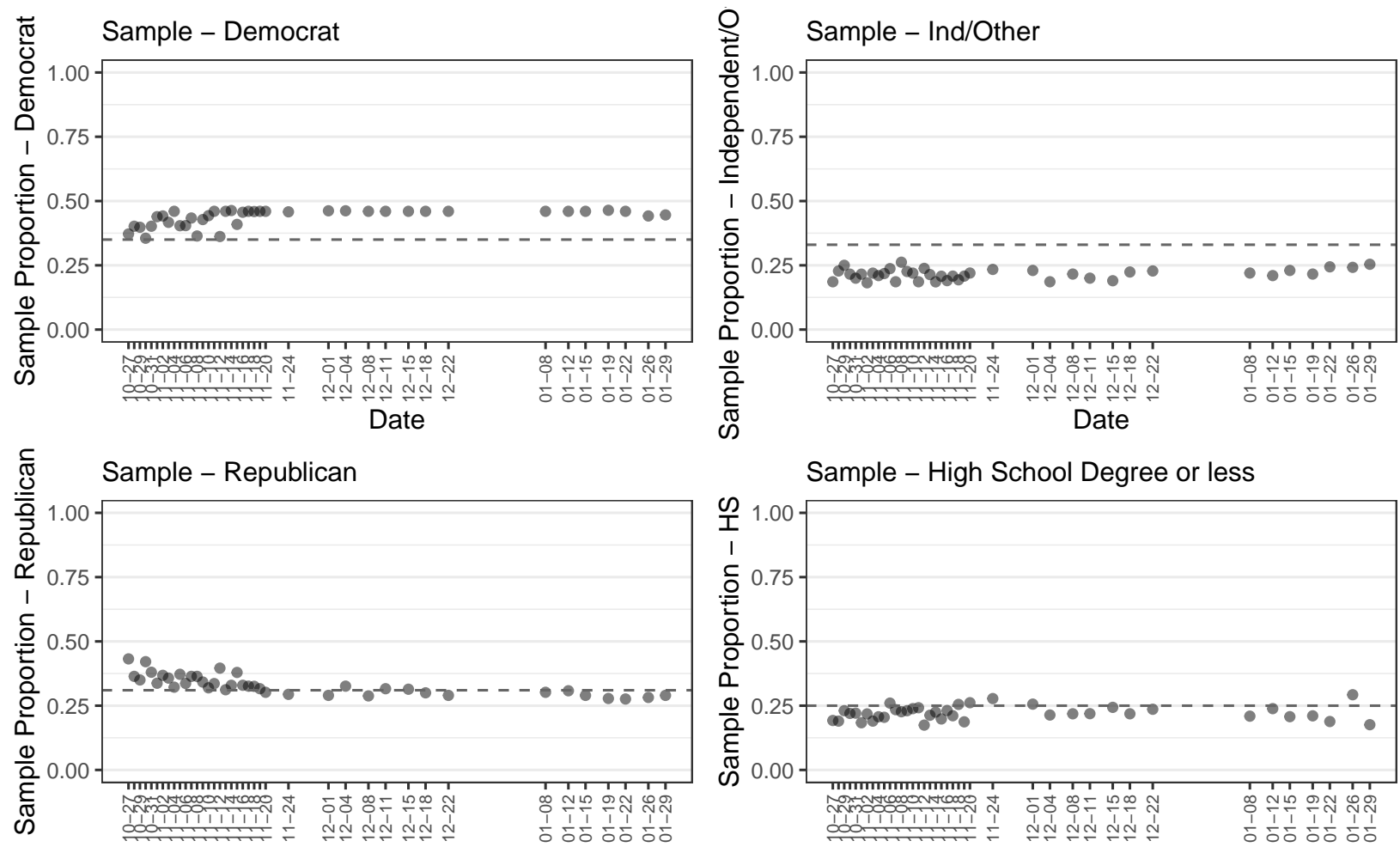

Sample - High School Degree or less

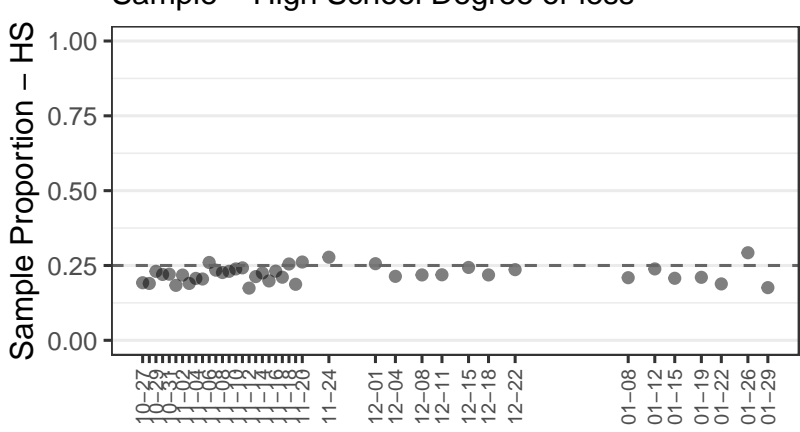

Date
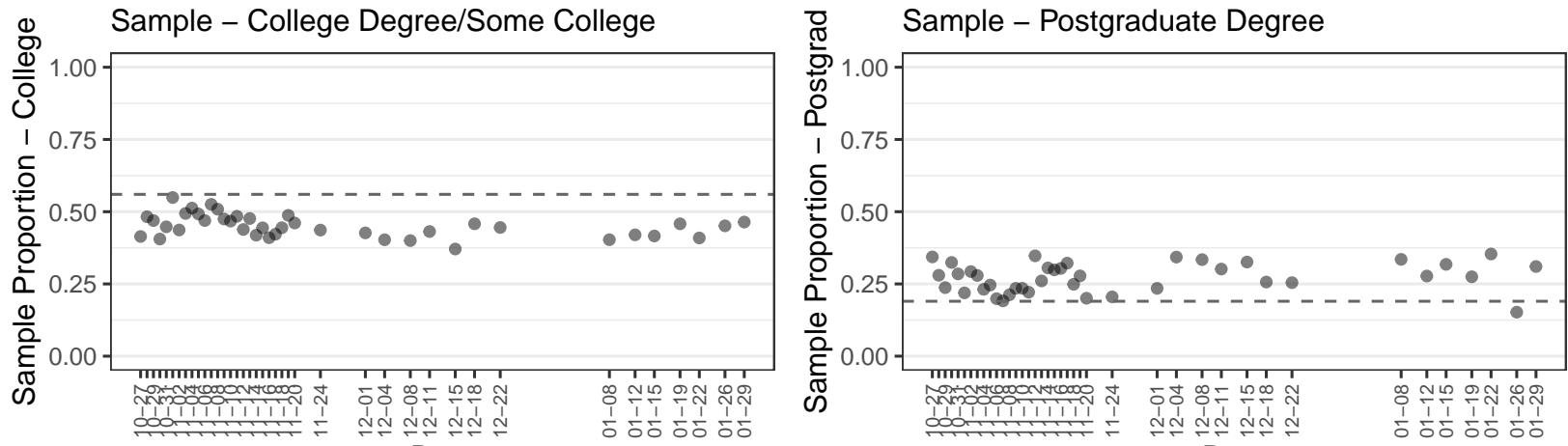

Date

Date

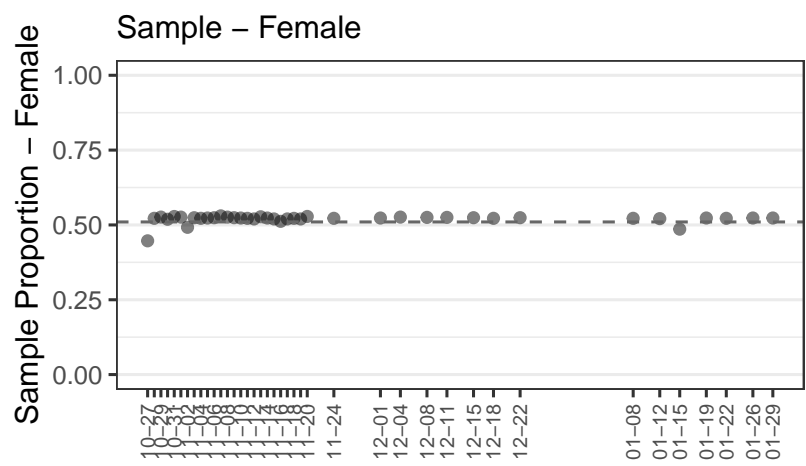

Date

Figure SI2: Sample Composition Over Time (2/2). The figure shows different the share of respondents falling into different demographic categories in each daily sample. The dotted line represents the group's share of registered voters. Categories where the points consistently fall above the dotted line are over-represented in the unweighted survey data. Categories where the points fall below are under-represented. All data drawn from Election Legitimacy Tracking Survey (ELTS). 
Outcome: Believes Biden Won

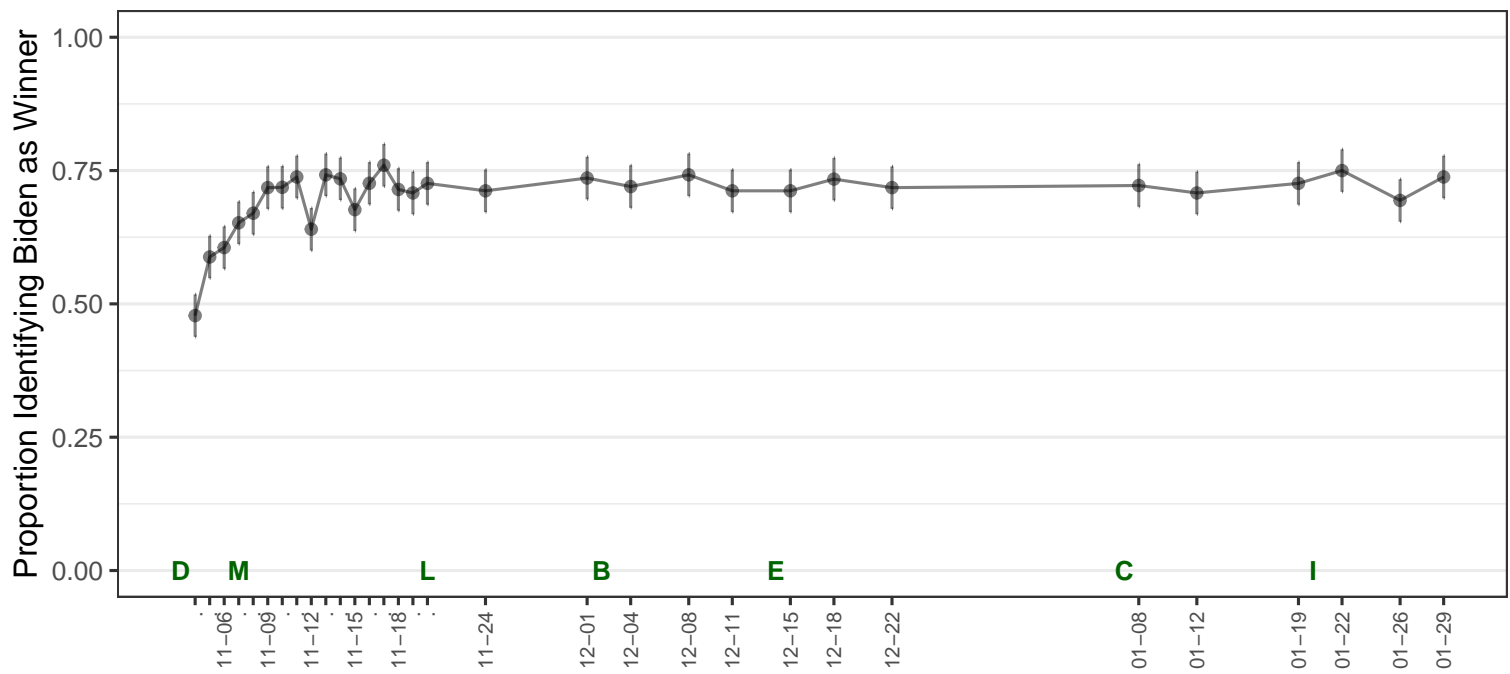

Outcome: Election Result Legitimate

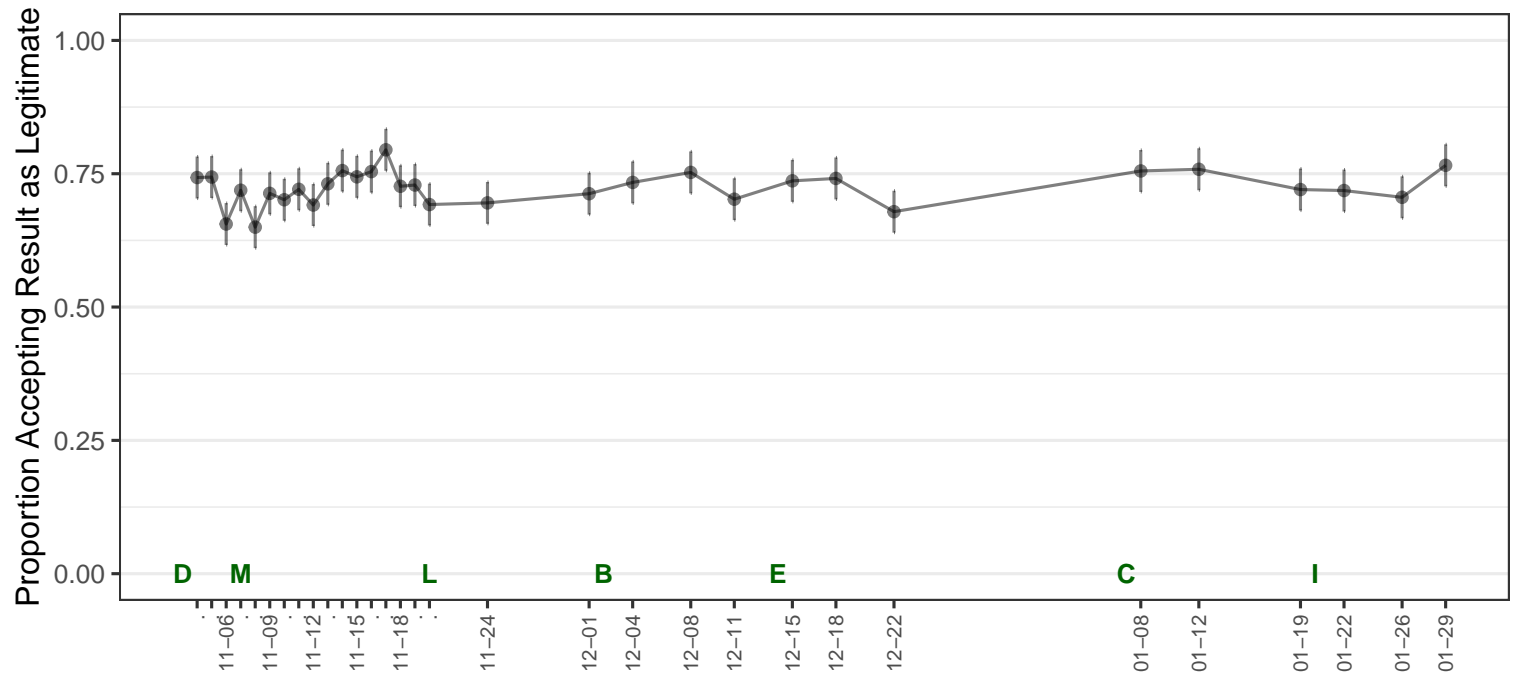

Figure SI3: Perceptions of 2020 election outcome (unweighted data). The top panel shows the proportion of respondents that answered "Joe Biden" to the question, "Who do you think won the 2020 presidential election?" The bottom panel shows the proportion that responded "Yes" to the question, "Do you accept the election results as legitimate?" Starting on November 8th, the legitimacy question was preceded by the sentence, "Major news networks have announced that Joe Biden is the winner of the 2020 presidential election." Letters mark significant political events: D = Election Day, Nov $3 ; \mathrm{M}=$ Race called by news networks, Nov 7; $\mathrm{L}=$ Trump invites Michigan legislators to White House, Nov 24 ; B = Barr says no evidence of fraud, Dec 2; E = Electoral College certifies Biden, Dec 15; C = Capitol insurrection, Jan 7; I = Inauguration Day, Jan 20. Line segments represent $95 \%$ confidence intervals. All data drawn from Election Legitimacy Tracking Survey (ELTS). 


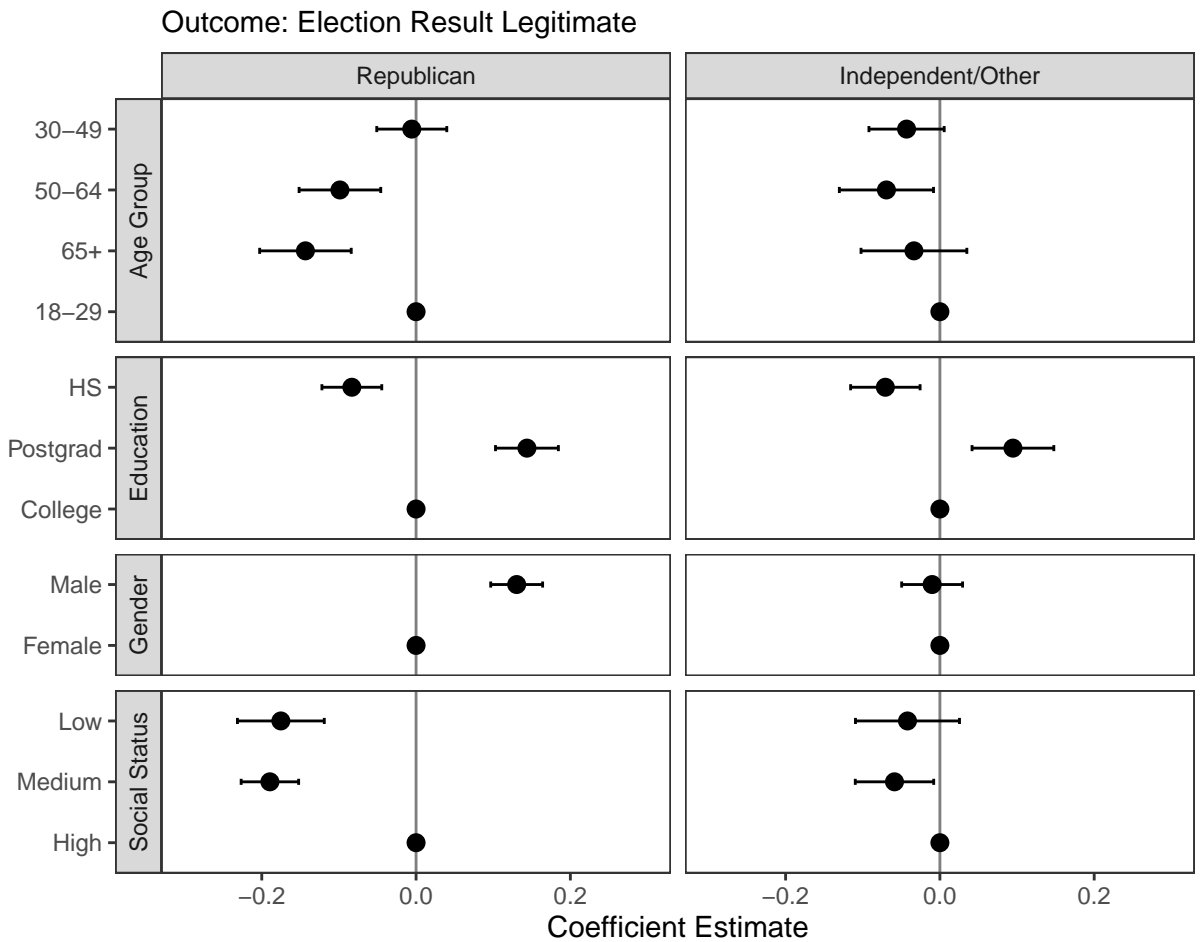

Figure SI4: Perceptions of 2020 election outcome by partisanship and demographics (unweighted data). The figure shows the coefficient estimates from a linear probability model where the binary legitimate variable was regressed on demographic covariates of interest. Starting on November 8th, the legitimacy question was preceded by the sentence, "Major news networks have announced that Joe Biden is the winner of the 2020 presidential election" - the estimates in this figure reflect data collected after that date. Line segments represent $95 \%$ confidence intervals. All data drawn from Electoral Legitimacy Tracking Survey (ELTS). 


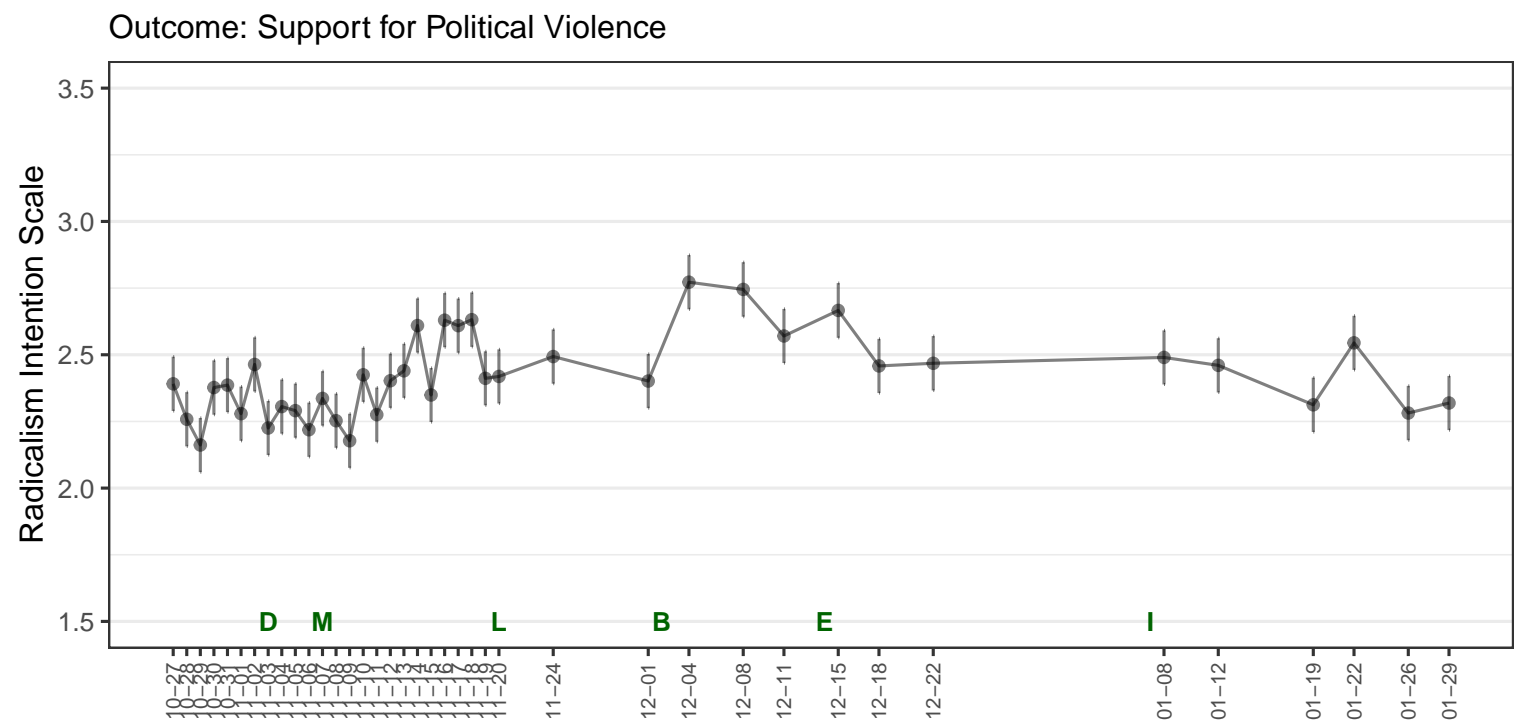

Figure SI5: Support for Political Violence. Letters mark significant political events: D = Election Day, Nov 3; $\mathrm{M}=$ Race called by news networks, Nov 7; $\mathrm{L}=$ Trump invites Michigan legislators to White House, Nov 24 ; B = Barr says no evidence of fraud, Dec 2; E = Electoral College certifies Biden, Dec 15; I = Capitol insurrection, Jan 7 . Line segments represent $95 \%$ confidence intervals. All data drawn from Election Legitimacy Tracking Survey (ELTS). 
(1/3) Suppose you are voting in a primary election between two Republican candidates who are running for Congress. Which candidate do you prefer?
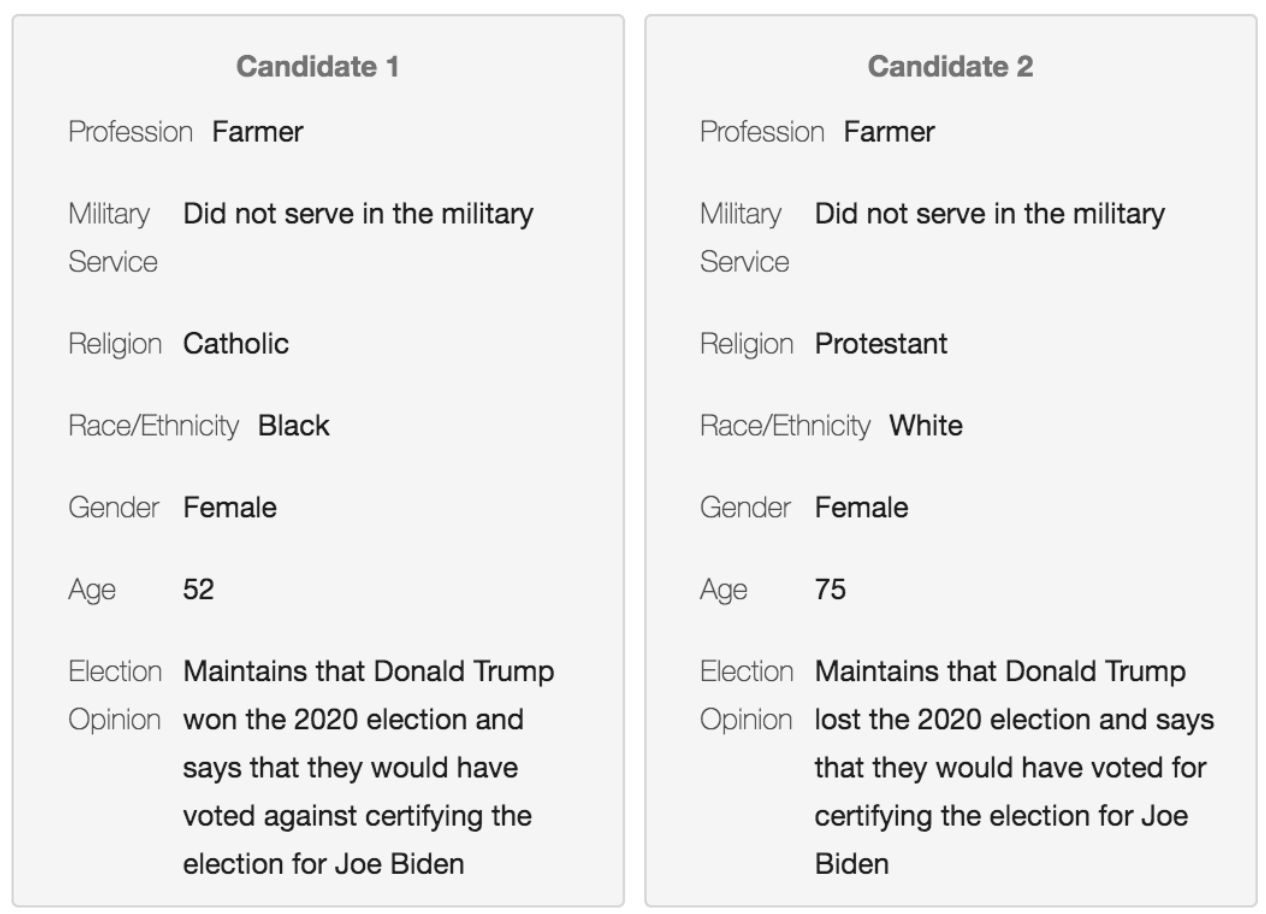

Figure SI6: Paired conjoint experiment prompt. The figure shows how the conjoint experiment appeared to respondents in the Electoral Legitimacy Tracking Survey (ELTS). 


\section{Question Wording}

Module: Radicalism Intention Scale (RIS) (Moskalenko and McCauley 2009)

In this section, you will be presented with a series of possible actions that you can carry out to promote your group's political rights and interests. By "your group," we mean the political, religious, or social group that you identify with the most. To what extent do you disagree or agree with the following statements?

V1. I would participate in a public protest against oppression of my group even if I thought the protest might turn violent.

1 - Strongly agree

2 - Agree

3 - Neither agree or disagree

4 - Disagree

5 - Strongly disagree

99 - No answer

V2. I would attack police or security forces if I saw them beating members of my group.

1 - Strongly agree

2 - Agree

3 - Neither agree or disagree

4 - Disagree

5 - Strongly disagree

99 - No answer

V3. I would encourage others to join violent protests against oppression of my group, even if I knew it was illegal.

1 - Strongly agree

2 - Agree

3 - Neither agree or disagree

4 - Disagree

5 - Strongly disagree

99 - No answer

V4. I would go to war to protect the rights of my group.

1 - Strongly agree

2 - Agree

3 - Neither agree or disagree

4 - Disagree

5 - Strongly disagree

99 - No answer

V5. I would retaliate against members of a group that had attacked my group, even if I couldn't be sure I was retaliating against the guilty party.

1 - Strongly agree 
2 - Agree

3 - Neither agree or disagree

4 - Disagree

5 - Strongly disagree

99 - No answer

Module: Election Outcomes

E1. Who do you think is most likely to win the presidential election? [administered preelection]

1 - Definitely Joe Biden

2 - Probably Joe Biden

3 - Both Joe Biden and Donald Trump are equally likely to win

4 - Probably Donald Trump

5 - Definitely Donald Trump

99 - No answer

E2. Who do you think won the presidential election? [administered postelection]

1 - Joe Biden

2 - Donald Trump

99 - No answer

E3. Major news networks have announced that Joe Biden is the winner of the 2020 presidential election. Do you accept the election results as legitimate?[administered postelection]

1 - Yes

$2-\mathrm{No}$

99 - No answer

Module: Candidate Identification

P5b. In the 2020 general election, who did you vote for?

1 - Donald Trump

2 - Joe Biden

3 - Someone else

4 - I am not sure

5 - No answer

P4. On each of the next several pages you will be presented with a statement. Please rate how much you agree or disagree with the statement on each page.

P4b. When people criticize [P5b piped text], it feels like a personal insult. 
1 - Strongly agree

2 - Agree

3 - Neither agree or disagree

4 - Disagree

5 - Strongly disagree

99 - No answer

P4f. When people praise the [P5b piped text], it makes me feel good.

1 - Strongly agree

2 - Agree

3 - Neither agree or disagree

4 - Disagree

5 - Strongly disagree

99 - No answer 